\title{
Evaluation of the hepatoprotective and antioxidant effects of Tegillarca granosa flesh body extract against potassium bromide toxicity via targeting the histomorphometry, chromosomal and expressions of TGF- $\beta 1$, VEGF and COX-2 genes in rats
}

\author{
Ali H. Abu AlmaATY ${ }^{1}$; Basma M. HENDAM²; Fayez Althobaiti ${ }^{3}$; Eman FAYAD ${ }^{3, *}$; Yasmin M. Abd El-AZIZ ${ }^{1, *}$ \\ ${ }^{1}$ Department of Zoology, Faculty of Science, Port Said University, Port Said, 42526, Egypt \\ 2 Department of Husbandry and Development of Animal Wealth, Faculty of Veterinary Medicine, Mansoura University, Mansoura, 35516, Egypt \\ ${ }^{3}$ Department of Biotechnology, Faculty of Science, Taif University, Taif, 21944, Saudi Arabia
}

Key words: Potassium bromide, Tegillarca granosa, Hepatic toxicity, Antioxidant biomarker, Histomorphometry, Chromosomal aberrations, Gene expression

\begin{abstract}
The hepatotoxic effect of potassium bromide (KBr) on rat liver tissues were determined, as well as the potential protective effect of Tegillaraca granosa (T. granosa) flesh body extract. Twenty adult male albino rats were equally distributed into four groups; Group (I) treated with physiological saline (control group), Group (II) was orally gavaged by $200 \mathrm{mg} / \mathrm{kg}$ of $T$. granosa body extract day after day, Group (III) was intoxicated by $\mathrm{KBr}(150 \mathrm{mg} / \mathrm{kg}$ bwt day after day orally) and finally, Group (IV) was given a combination of T. granosa flesh body extract plus $\mathrm{KBr}$ with similar doses in the second and third groups. At the end of one month, blood, liver tissue and bone marrow samples were collected to be used for the required laboratory examinations. In response to KBr toxicity, there was a significant increase in serum antioxidant biomarkers, which was accompanied by a significant change in hepatocyte ultrastructure and a significant change in carbohydrate and protein levels within the liver organ. In addition, $\mathrm{KBr}$ intoxication resulted in a substantial increase in the incidence of chromosomal aberrations such as holes, splits, deletions, fragments, ploidy, and ring chromosomes, as well as significant upregulation of TGF-1, VEGF, and COX-2 gene expression. The hepatotoxic effect of $\mathrm{KBr}$ was counteracted by treatment with $T$. granosa flesh body extract. T. granosa flesh body extract has a curative antioxidant and numerous protective effects against $\mathrm{KBr}$ hepatotoxicity.
\end{abstract}

\section{Introduction}

Potassium bromide $(\mathrm{KBr})$ is an antiepileptic agent used in the food and pharmaceutical industries. In veterinary medicine, it is also used as an anti-convulsant, sedative, and monotherapy (Alexander and Eric, 2009). Potassium bromate is used widely in food and cosmetic industries to induce oxidation. It is used in bakeries as a food additive and flavor improver giving strength and sponge like characters to the dough, It is also reduced to potassium bromide $(\mathrm{KBr})$ during the baking process, making it a more stable compound (Bayomy et al., 2016). Potassium bromate $(\mathrm{KBrO} 3)$ is used broadly in food and cosmetic industries. Also, Potassium bromate is reduced to potassium bromide $(\mathrm{KBr})$

*Address correspondence to: Eman Fayad, e.esmail@tu.edu.sa; Yasmin M. Abd El-Aziz, yasminabdelaziz2012@yahoo.com Received: 25 May 2021; Accepted: 02 July 2021 that is a more stable compound. Though, this reaction may be incomplete, but some $\mathrm{KBrO} 3$ remains, and leads to potential oxidative damage. So, the usage of $\mathrm{KBrO} 3$ in bread production is prohibited in some countries. And it is recommended to use $\mathrm{KBr}$ better than $\mathrm{KBrO} 3$ (Kaya and Topaktaş, 2007; Ahmad et al., 2012).

In dogs and cats, raising the dosage of $\mathrm{KBr}$ to around $35 \mathrm{mg} / \mathrm{kg} /$ day orally causes stomach pain and vomiting (Bagley et al., 2013). In dogs, potassium bromide is used to treat seizures caused by phenobarbital. When using a dosage of $22-40 \mathrm{mg} / \mathrm{kg}$ orally daily, the side effect of potassium bromide is upregulated; in the doge, the half-experimental period is 25 days (15-45 days); potassium bromide should be provided through food diets. After 30-60 days, the steady state concentration of $\mathrm{KBr}$ in serum is reached (Lorenz et al., 2011). In one study, $\mathrm{KBr}$ was used to treat coughing and lung disease in cats. The bromide is only bound to plasma protein before being excreted by the kidney. In general, when $\mathrm{KBr}$ is taken orally, it causes inflammation of 
the mucosa layer in the stomach (Silverstein and Hopper, 2009). Potassium bromide has a bromide content of around 67 percent per unit weight. Since a single dose of potassium bromide has no effect on plasma, disorder can be caused by a long-term accumulation of $\mathrm{KBr}$ doses (Jennifer, 2018).

$\mathrm{KBr}$ could generate reactive oxygen species (ROS) within cells and tissues which cause tissue injury. Also, ROS, free radicals and other oxidative stress-related intermediates lead to death of cell (Novo and Parola, 2008; Friedman, 2008). Moreover, these free radicals including superoxide, peroxyl radicals, hydroxyl radicals, hydrogen peroxide and hypochlorous (Finkel and Holbrook, 2000) cause damage in DNA leading to double strand break and affect expression of some genes (McCord, 2000). Bromate ions that are produced from $\mathrm{KBr}$ provoke oxygen radicals that damage DNA as proved by aggregation of 8 -OHdG levels responding to oxidative stress (Lee et al., 1996; Umemura et al., 1995).

Tegillarca granosa is considered as a marine invertebrate which belongs to the Arcidae family under Phylum Mollusca, They possess a good taste, high nutritive and medical value. So they have been used as food and traditional medicine for many centuries and attract attention for the cure of tumors, anemia and inflammation (Guo and Li, 2003). This cockles are contains carbohydrates, protein, lipid and other important antioxidant martials that have roles in human health. According to season, the antioxidants of $T$. granosa are various. In China used T. granosa for treating chronic illnesses and cancer as traditional medicine (Nguyen and Rohmah, 2017). The natural activity of product is haishengsu (HSS) in T. granosa extract which plays role in cancer treated cells in vitro. When put HSS extract on cancer cells in vitro, inhibited the aggregation of this chronic cancer cells and stimuli the apoptosis of cancer cells occur, so the HSS used as traditional therapy for liver, lung, brain and kidney carcinoma (Wang, 2013).

According to Xue et al. (2018), they used HSS isolated from T. granosa for inhibition several types proliferation of cancer tisues. They noticed that HSS induce apoptosis to suppress the growth of female nude mice hepatocellular carcinoma tumor. The doses were used 62.5 to $250 \mathrm{mg}$ of T. granosa $/ \mathrm{kg}$ for mice. Also, the $5 \%$ of T. granosa powder as a treatment for rats by used of high fat diet, which results in endothelial dysfunction of blood vascular. They noticed that T. granosa which improves the endothelial function and blood glucose (Promyo et al., 2020). Also, in other previous literature, they used $T$. granosa as a treatment for malnourished rats because of being treated with dried rice. Then, the dried rice was used as $12.5 \%, 25 \%$ and $50 \%$ of T. granosa powder. They noticed that increased or rats' body weight with increasing of different percentages of T. granosa compared to control group (Solang and Adriani, 2021).

The transforming growth factor beta (TGF- $\beta$ ) is a pleiotropic cytokine that is involved in cell survival, proliferation, differentiation, and angiogenesis (Achyut and Yang, 2011; Dooley and Dijke, 2012). TGF- $\beta 1$ is one of TGF- $\beta$ isoforms, which arrests the cell cycle in the G1 phase and elicits inhibition of cell proliferation and triggering apoptosis (Pasche, 2001).

Additionally, VEGF is identified as a vascular permeability factor, is the most potent in the angiogenesis process (Yancopoulos et al., 2000; Karkkainen and Petrova, 2000). Also, it possesses a vital role in many cases of physiological and pathological angiogenesis and known as a survival factor of endothelial cells (Gerber et al., 1999). Meanwhile, it was observed that suppression of interaction between VEGF and its receptor could significantly diminished development of liver fibrosis and angiogenesis (Rosmorduc et al., 1999). Cyclooxygenase (COX) is an enzyme that is involved in the intermediation of inflammation, activates the synthesis of prostaglandins from arachidonic acid (Meade et al., 1993). There are two distinct enzymes, COX-1 and COX-2 were exhibited, COX-1 that is expressed in most cells. T. granosa has been applied in the research of genetics that comprises cDNA cloning and gene expression (He et al., 2009).

This study was carried out to verify the hepatotoxic effects of $\mathrm{KBr}$ drug and also, to spot light on the protective effects of Tegillaraca granosa flesh body extract toward these hazardous effects using male albino rats as an experimental model. This was speculated by the evaluation of antioxidant markers, chromosomal aberrations and expression patterns of TGF- $\beta 1$, VEGF and COX- 2 genes and the concerned tissue structure changes.

\section{Materials and Methods}

\section{Test compounds and chemicals}

Potassium bromide ( $\mathrm{KBr}$ ) with $\geq 99 \%$ purity, CAS number 243418 and molecular weight 119.00 was purchased from Sigma-Aldrich Co., St. Louis. $\mathrm{KBr}$ was diluted with distilled water and then kept in brown glass vials at $4^{\circ} \mathrm{C}$. Fresh solutions were prepared every week as needed.

\section{Preparation of Tegillarca granosa flesh body extract}

Tegillarca granosa animals (Fig. 1) were collected from the Port Said shore, Port Said City, Egypt. T. granosa flesh body extract was prepared according to method of (Yang et al., 2019). They were washed with water; left to dry then muscles were removed, minced to a fine homogenate, then were defatted according to (Wang et al., 2013), then mixing the homogenate and isopropanol in a ratio of 1:4 (w/v) and moved continuously for $4 \mathrm{~h}$ at $35^{\circ} \mathrm{C}$. The isopropanol was replaced every $2 \mathrm{~h}$. The supernatant was removed, and the sediment was freeze-dried and stored at $-20^{\circ} \mathrm{C}$.

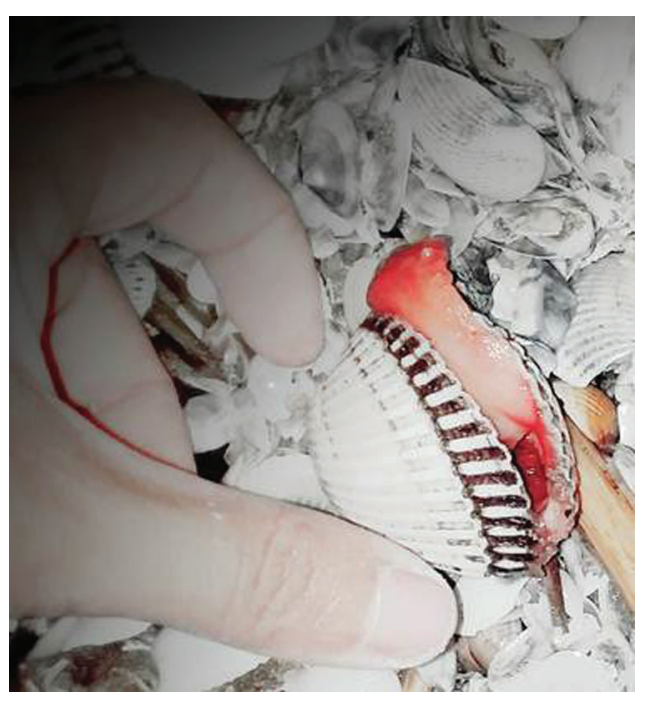

FIGURE 1. Tegillarca granosa as Mollusca bivalve. 


\section{Experimental animals}

Twenty adult male albino rats (Rattus norvegicus) weighing 110-130 g were obtained from the laboratory animals' farm (Faculty of Science, Port Said University). Rats can be used because the advantages and similarities to humans, the rat experimental model is of high importance for studying disease. This is the reason we focused on this model in order to evaluate all the pros and cons (Tomina et al., 2007). Laboratory rats provide ideal animal models for biomedical research and comparative medicine studies because they have many similarities to humans in terms of anatomy and physiology. Scientists have deep understanding of rat physiological mechanisms, various rat models that mimic human diseases (Gibbs, 2004; Waterston et al., 2002). We chose the animal size because assumptions of one way a nova don't depend on absolute number of sample size but depend on the number of groups (Blair, 1981). In our study we used four groups (1-control, 2-treatment, 3-toxic and 4combination of them). The number of the experimental groups follow the assumptions of the test used and does not interfere with them.

The animals were suited to laboratory conditions for 2 weeks before the experiment was started. They were kept in a temperature-controlled environment $\left(25 \pm 1^{\circ} \mathrm{C}\right)$ with water and food available to them ad libitum and they were maintained in plastic cages under controlled lighting conditions (12:12 light:dark cycle) relative humidity (50 \pm $5 \%)$ and temperature $\left(37 \pm 2^{\circ} \mathrm{C}\right)$, through the experimental period. Then all animals were equally distributed into four groups with five rats in each group. Group I (control group) orally received physiological saline, Group II was orally gavaged by $200 \mathrm{mg} / \mathrm{kg}$ of $T$. granosa flesh body extract day after day (the first study) and Group III orally received $\mathrm{KBr}$ at dose of $150 \mathrm{mg} / \mathrm{kg}$ bwt day after day (Safdari et al., 2017). And finally Group IV that orally applied with the combined treatment of $\mathrm{T}$. granosa and $\mathrm{KBr}$ at the same previous doses. These procedures were repeated for about 30 days. All the experimental procedures were conducted after taking prior approvals from Zoology department at Faculty of Science, Port Said University, Egypt.

\section{Collection of samples}

At the end of the study period, animals were fasted for about twenty four hours before sacrifice. Each rat was injected intraperitoneally with colchicine powder (Sigma Aldrich, 6486-8 CAS number and molecular weight 399.44) at dose of $4 \mathrm{mg} / \mathrm{kg}$ bwt two hours before the time of sample collection and sacrifice. Two hours after colchicine administration, blood samples were obtained from orbital vessels of both control and treated groups. They were left for $15 \mathrm{~min}$ to clot at room temperature, then centrifugated at $3000 \mathrm{rpm}$ for $15 \mathrm{~min}$ in order to separate serum that was kept at $-20^{\circ} \mathrm{C}$ for further biochemical analysis of antioxidant markers. Then all animals were euthanized by cervical dislocation under sodium pentobarbital anesthesia $(60 \mathrm{mg} / \mathrm{kg})$.

\section{Evaluation of antioxidant markers in hepatic tissue}

The antioxidant biomarkers were evaluated such as total antioxidant capacity (TAC), catalase (CAT), and glutathione s-transferase (GST). Antioxidant activities were measured kinetically using commercially available kit obtained from Bio-Diagnostic Company (Giza, Egypt) according to the manufacturer's instructions (pamphlet) the assays were done.

\section{Bright field microscopic examinations}

The liver tissue samples were removed from each animal for light examination microscopy, they were immersed in $10 \%$ formalin solution as soon as a fixation step for prevention from maceration by action of bacteria, lytic enzymes and other postmortem disorders that could degrade tissue and also hardens of liver for cutting into thin ribbons without damage of hepatic tissue. The pieces of liver were embedded into paraplast wax block and cut the produced ribbon at 4 microns of thickness by microtome (Leica, Germany) and prepared for histological and histochemical examinations. Sections were stained with $\mathrm{Hx} \& \mathrm{E}$ for detecting the general structures of the liver tissues, PAS reaction for staining carbohydrates content and Mercury bromophenol blue for staining the total protein content in the hepatocytes. The stained sections of the liver were examined under a light filed microscopy (Leica, Germany) (Bancroft and Gamble, 2008).

\section{Transmission electron microscopic examination}

The liver was removed surgically and then. The hepatic tissues were prepared for transmission electron microscopy. According to (Karnovsky, 1965), for $2 \mathrm{~h}$ at room temperature, the hepatic tissue samples immediately transferred into the solution of $2.5 \%$ glutaraldehyde in $0.1 \mathrm{M}$ phosphate buffer. After $2 \mathrm{~h}$ the liver samples were immersed in the new fixative solution at $4^{\circ} \mathrm{C}$ overnight then washed in $0.1 \mathrm{M}$ sodium phosphate buffer $+0.1 \mathrm{M}, \mathrm{pH} 7.2$, three times. Then, hepatic tissue samples were kept in a post-fixation step with osmium tetroxide for $1 \frac{1 / 2}{2}$ hours at $4^{\circ} \mathrm{C}$ then washed again in buffer, $\mathrm{pH}$ 7.2. After that, tissue samples were transferred in a series of ethyl alcohol as $70 \%$ 90\% 95\% 100\% ethanol (two changes), at each step with incubations for $5 \mathrm{~min}$, then $100 \%$ ethanol for 10 minutes. Dehydrated tissues via infiltrated the tissue in propylene oxide and embedded in Araldite 502 Epon resin. By use ultramicrotome, sections of $85 \mathrm{~nm}$ were obtained, were picked up onto the finder grids, and stained with lead citrate and uranyl acetate (Makanya et al., 2011). Then the tissue specimens were examined by a transmission electron microscope (JEOL JEM -2100, USA) at an accelerating voltage of $80 \mathrm{kV}$ at Electron Microscopy Unit at Mansura University, Mansura, Egypt.

\section{Chromosomal aberration assay}

The two femurs were quickly removed, muscles were cleaned away from bones and the cartilignous epiphyses were cut off. The bone marrow was removed from femur and air-dried metaphase procedures according to Tjio and Whang (1962); Singh and Sankhla (2010). The slides were subsequently stained with 5\% Giemsa stain for 15-20 minutes, cleaned in distilled water and were left to dry. A bout 100 well spread slides per rat were selected for screening. Hence, a minimum of 500 metaphases were used to determine all types of chromosomal aberrations. The slides were photographed under a bright microscopy (Leica, Germany). 
Quantitative real-time PCR for TGF- $\beta 1, V E G F$ and COX-2 genes

Total RNA extraction, cDNA synthesis and real-time PCR analysis To evaluate gene expression levels, liver tissue samples were collected in liquid nitrogen and stored at $-80^{\circ} \mathrm{C}$ until analysis. Total RNA was extracted from $50 \mathrm{mg}$ using Trizol (iNtRON Biotechnology) according to the manufacturer's instructions. The integrity of RNA was confirmed by ethidium bromide stained $2 \%$ agarose gel electrophoresis. RNA concentration was measured by Nano drop (UV-vis spectrophotometer Q5000/ Quawell, USA). Two $\mu \mathrm{g}$ of RNA sample was reverse transcribed using SensiFAST ${ }^{\mathrm{Tm}}$ cDNA synthesis kit (Bioline, UK) following the manufacturer's manual). Gene expression profiling was performed in a Stratagene MX3000 $\mathrm{P}$ real-time PCR using SensiFast SYBR Lo-Rox kit (Bioline). The sequence of the primers was shown in Tab. 1. The reaction mixture was carried out in a total volume $20 \mu \mathrm{l}$ that contained $2 \mu \mathrm{L}$ of cDNA, the gene-specific primers $(0.5 \mu \mathrm{M}$ each), and $10 \mu \mathrm{L}$ of SYBR and DNase free-water up to $20 \mu \mathrm{l}$. The thermal cycling conditions were as follow:initial denaturation at $95^{\circ} \mathrm{C}$ for $10 \mathrm{~min}$, followed by 40 cycles at $95^{\circ} \mathrm{C}$ for $15 \mathrm{~s}$, annealing at $60^{\circ} \mathrm{C}$ for $1 \mathrm{~min}$ and extension at $72^{\circ} \mathrm{C}$ for $30 \mathrm{~s}$. At the end of the amplification phase, a melting curve analysis was performed to confirm the specificity of the PCR product. Relative fold changes in the mRNA expression of the studied target genes were calculated and described using the comparative $2^{-\Delta \Delta \mathrm{Ct}}$ method (Ct: cycle threshold) with the GAPDH as an internal reference gene to normalize target gene expression levels (Livak and Schmittgen, 2001).

\section{Statistical analysis of data}

Data were expressed as mean \pm SE. Statistical comparisons between different parameters among all groups were achieved by one-way ANOVA using the SPSS 16.0 computer program and Chi-square test. Tukey's multiple comparisons post hoc test was executed to compare mean values between all the experimental groups. The differences between values were considered statistically significant when the $p$ value was less than 0.05 .

\section{Results}

Effect on status of antioxidant biomarkers in hepatic tissue The results of the hepatic antioxidant biomarkers were illustrated in Fig. 2. It was elicited that the TAC, CAT and
GST activities were measured in the experimental groups. Group I (control) showed the normal levels of TAC and the activities of CAT and GST antioxidant enzymes that were the same as Group II (T. granosa) with nonsignificant difference. Meanwhile, in Group III (KBr) the levels of the biochemical antioxidants were revealed significantly down regulated when compared to Group I $(0.23 \pm 0.009$ and $0.02 \pm 0.003)$. In addition, the activity of enzyme was significantly decreased from $402.02 \pm 38.21$ in Group I to $285.17 \pm 51.87$ in Group III. Also, the measured levels of GST are significantly down regulated from $6.97 \pm 0.50$ in Group I to $3.32 \pm 0.33$ in Group III.

On the other hand, the deleterious effects of $\mathrm{KBr}$ were modulated through the treatment with T. granosa flesh body extract. It was noticed that the TAC displayed an increase response to the administration of T. granosa as depicted in Group II and Group IV when compared to Group III (0.28 $\pm 0.006,0.13 \pm 0.004$ and $0.02 \pm 0.003$ respectively). The same effect was detected in the CAT activity; it cleared a significant upregulation in Group II and Group IV when compared to Group III $(518 \pm 39.66,389 \pm 52.46$ and $285.17 \pm 51.87$, respectively). Also, the activity of GSH modulated in Group II and Group IV in comparison with Group III with significant elevation $(6.52 \pm 0.42,4.27 \pm 0.33$ and $3.32 \pm 0.33$, respectively).

\section{Histopathological investigations}

\section{Light microscopy (LM) study that stained with $H x \& E$}

The normal structure of Group I (control) is displayed in (Figs. 3A and 3B). There are normal polyhedral hepatocytes that noticed with single nuclei or binucleated that is oval or viewed rounded. Generally, no noticeable histological changes in liver from rat of Group II (T. granosa flesh body extract) when compared to Group I (Figs. 4A and 4B). However, the liver of rats which intoxicated with $\mathrm{KBr}$ (Group III) revealed a dilation of the sinusoids (Figs. 5A and $5 \mathrm{~B})$. The central veins were dilated, detachment from the lining endothelial cells and Kupffer-Browicz cells were activated as noticed by enlargement (Fig. 5B). Also, erosion of the endothelial lining of central portal vein (Fig. 5A) was observed. In some hepatocytes, vacuolar degeneration was noticed. And some nuclei were showed signs of karyorrhexis, karyolysis and pyknosis shapes (Figs. 5A and 5B). While, the group which treated with $T$. granosa flesh

TABLE 1

Forward and reverse primers used in QRT-PCR analysis

\begin{tabular}{lll}
\hline Target gene & Primers sequences & Reference \\
\hline \multirow{2}{*}{ TGF- $\beta 1$} & F:5-CCTGCAAGACCATCGACATG-3 & (Saad et al., 2019) \\
& R:5-GCGAGCCTTAGTTTGGACAG-3 & \\
VEGF & F:5-ATCATGCGGATCAAACCTCACC-3 & (Ibrahim et al., 2018) \\
& R:5-GGTCTGCATTCACATCTGCTATGC-3 & \\
COX-2 & F:5-TTCAAATGAGATTGTGGAAAAAT-3 & (Anusha et al., 2019) \\
& R:5-AGATCATCTCTGCCTGAGTATCTT-3 & \\
GAPDH & F:5-CCAGGGCTGCCTTCTCTTGT-3 & (Abd El-Aziz et al., 2019) \\
& R:5-CTGTGCCGTTGAACTTGCCG -3 & \\
\hline
\end{tabular}


A

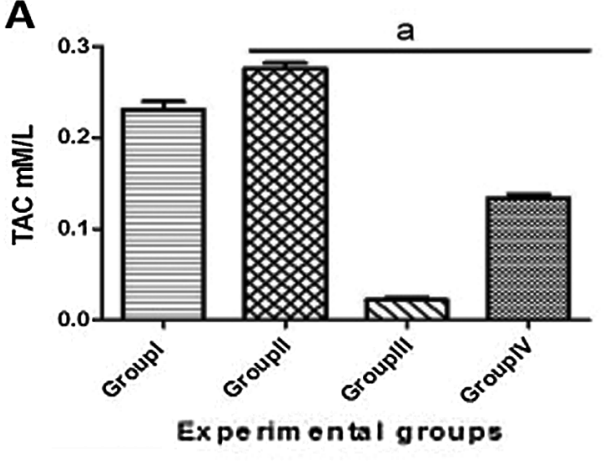

B

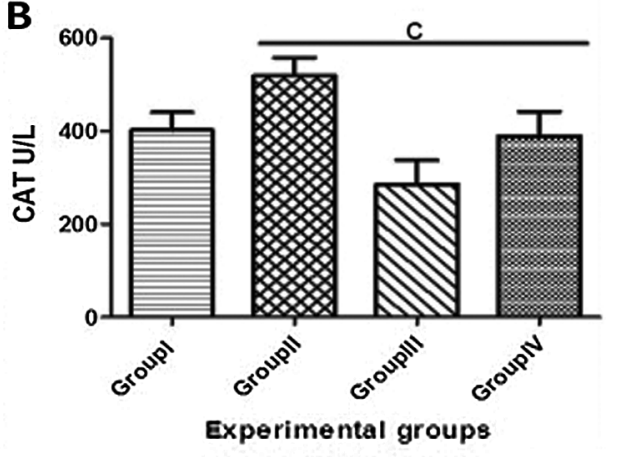

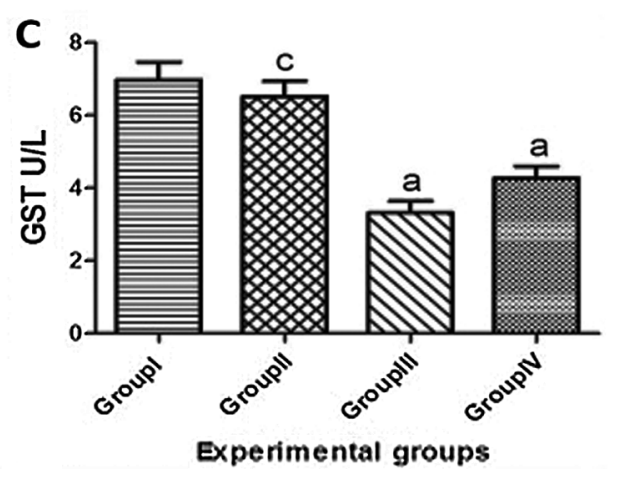

FIGURE 2. Serum antioxidant activities: TAC (A), CAT (B) and GST (C) of male albino rats that orally gavaged with $\mathrm{KBr}(150 \mathrm{mg} / \mathrm{kg}$ bwt) day after day and they were treated orally with $T$. granosa flesh body extract $(200 \mathrm{mg} / \mathrm{kg}$ bwt $)$ day after day. Data are presented as mean \pm SEM $(\mathrm{n}=10)$. The different astress indicates significant difference between treated groups. Differ significantly at $p<0.05$.
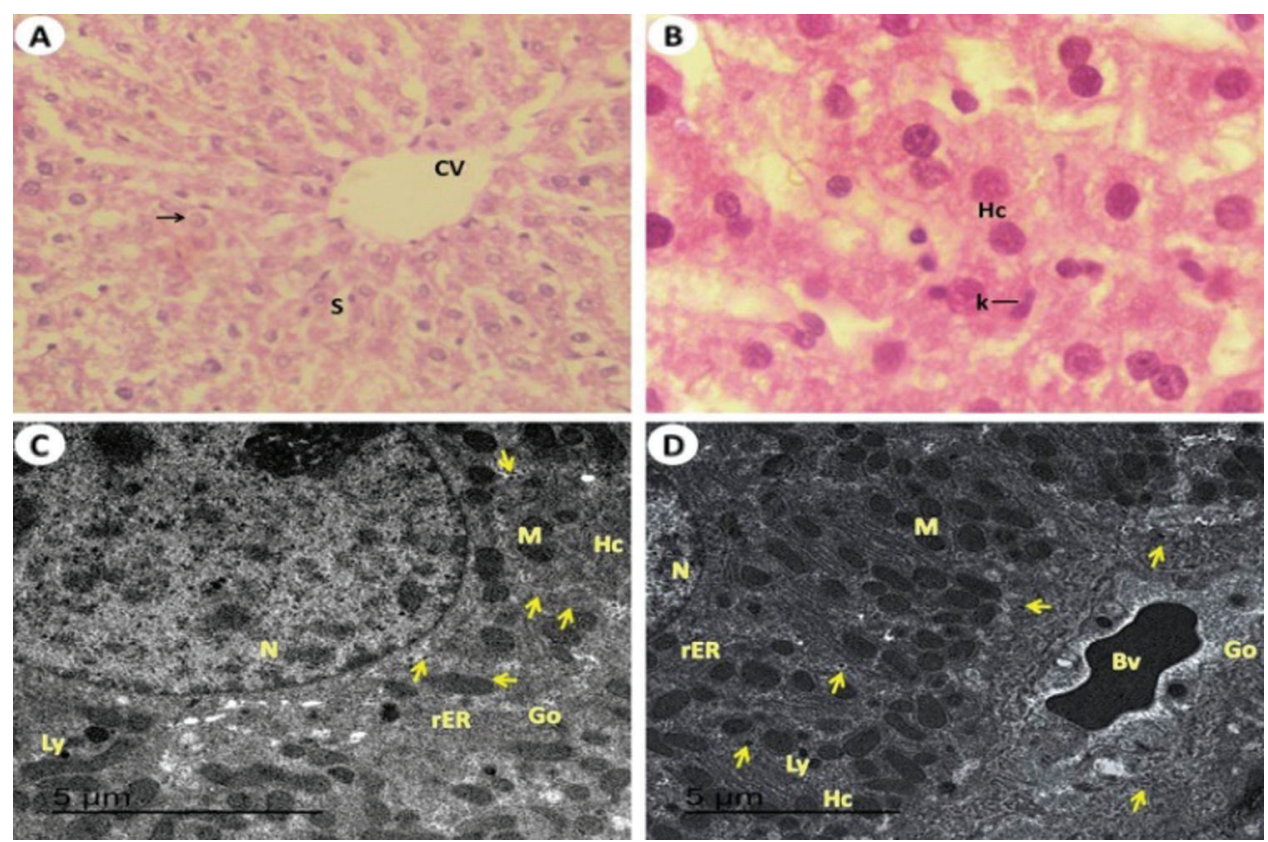

FIGURE 3. Light and electron investigations (A) Liver section of control rats (Group I) that shows the endothelial cells (En) are lined central vein $(\mathrm{CV})$, hepatic strands (Hs), hepatic cells $(\mathrm{Hc})$, Kupffer cells $(\mathrm{K})$, nucleus $(\mathrm{N})$ and noticed the hepatic blood sinusoids (S) are normally narrow (H.E., 400 X), (B) Enlarged part from the liver section notices the normal structure of hepatic cells, binucleated cells (BC), Kupffer cells $(\mathrm{K})$, clear cytoplasm $(\mathrm{Cy})$ with nuclei $(\mathrm{N})$ in position nucleolus $(\mathrm{Nu})$ and showed the hepatic blood sinusoids $(\mathrm{S})$ are normally spaces (H.E., $1000 \mathrm{X}$ ), (C) Healthy normal liver is detected with normal large size of hepatocytes (Hc) with euchromatic nucleus (N), normal rough endoplasmic reticulum (rER), The cytoplasm contains numerous normal of mitochondria (M), mitochondria (M), Golgi apparatus (Go), rough endoplasmic reticulum (rER) and lysosome (Ly) and glycogen granules (arrows) are visible (15000 X) and (D) The normal numerous and size of kupffer cells (10000 X).

body extract plus $\mathrm{KBr}$ (Group IV) showed detected hepatocytes with advanced degree of restoration of normal architecture as compared with the potassium bromide induced rats (Group IV) (Fig. 6A). The liver cells recognized almost intact without vacuolization (Fig. 6A). Some liver tissues appeared with more improvement that defined outlines around the central vein, narrow blood sinusoids, normal nuclei either single or binucleated, some pyknotic cells and hypertrophied Kupffer cells were recognized (Figs. 6A and 6B). 

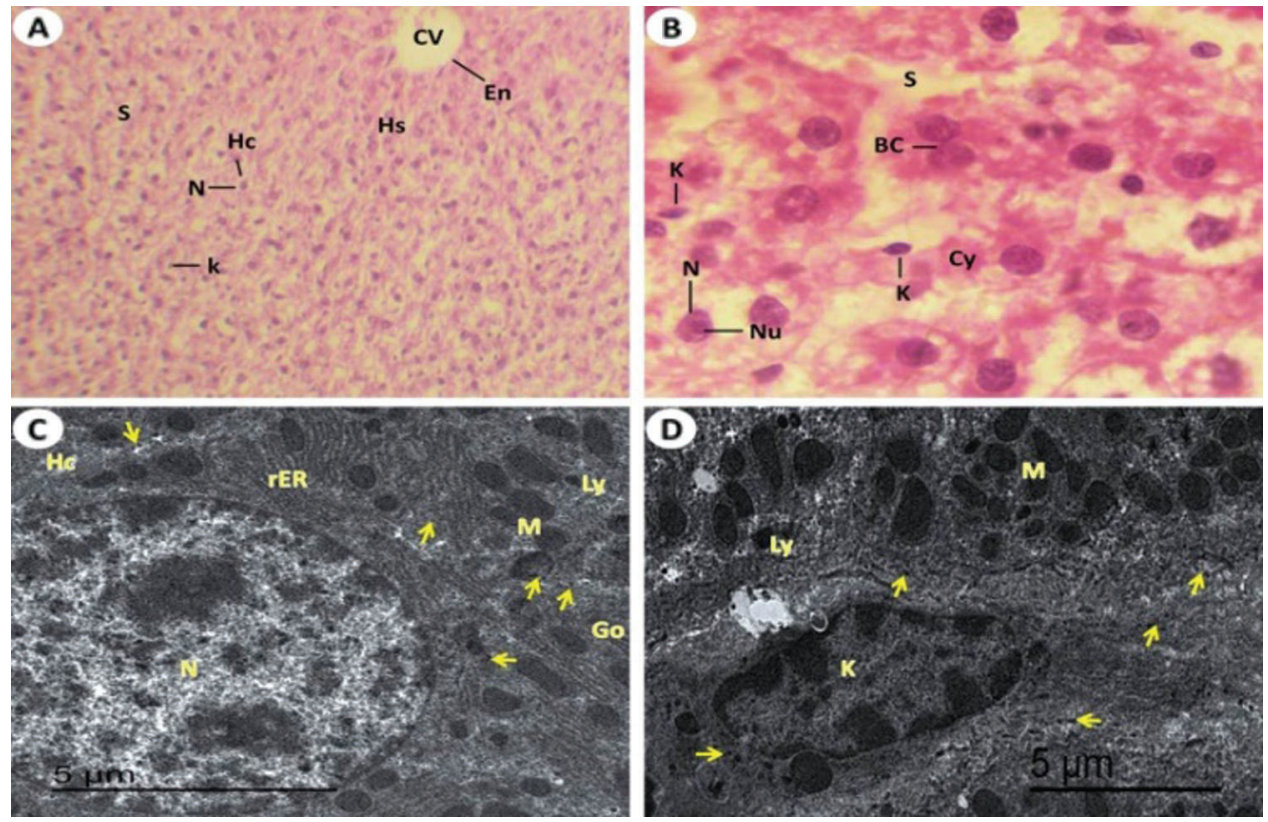

FIGURE 4. Light and electron investigations (A) Hepatic section by light microscope of rats which received T. granosa flesh body extract (Group II) that is similar to control (Group I) hepatocytes inside its strands, central vein (CV), nucleus (arrow) and intact appearance of hepatic blood sinusoids (S) (H.E., $400 \mathrm{X}$ ), (B) Enlarged part from the liver section displays intact the architecture of hepatocytes (Hc) and Kupffer cells (K) (H.E., $1000 \mathrm{X}$ ), (C) ultrastructure of hepatocytes (Hc) with normal lysosome, rough endoplasmic reticulum, Golgi apparatus, Kupffer cells, normal blood sinusoidal spaces and normal glycogen granules (arrows) content (15000 X) and (D) The normal of hepatocytes $(\mathrm{Hc})$ with nucleus $(\mathrm{N})$, blood vessel $(\mathrm{Bv})$ and intact the rest of organelles as same as in the control liver of rat (12000 X).

\section{Transmission electron microscopy (TEM) study}

Ultrastructure of liver section from control rats (Group I) showed normal ultrathin of hepatic tissues with normal large size of hepatocytes with euchromatic nucleus. The cytoplasm of hepatic cords contains normal numerous mitochondria, Golgi apparatus, rough endoplasmic reticulum, normal lysosome and normal contents of glycogen granules (Figs. 3C and 3D). The ultrathin of liver from rat received T. granosa flesh body extract (Group II) showed the hepatocytes which similar to the control liver rats (Group I) (Figs. 4C and 4D). However, the liver of rats which exposed to $\mathrm{KBr}$ (Group III) had seen dilation of the hepatic blood sinusoids, hepatocytes with necrotic stages, blood vessels are engorged with blood and the glycogen granules contents are decreased, numerous and large in size of lysosome, rough endoplasmic reticulum with tubular dilated, Golgi apparatus with dilated cisternae, numerous swollen of immune Kupffer cells vacuoles formation in the cytoplasm of hepatocytes and large dilated blood sinusoidal spaces (Figs. 5C-5F). While, rats treated with $T$. granosa flesh body extract plus $\mathrm{KBr}$ (Group IV) showed degree of restoration in the number of lysosome, Kupffer cells. Some of blood vessels are engorged with blood and enhancement of numerous mitochondria, rough endoplasmic reticulum and Golgi apparatus was detected (Figs. 6C-6E).

\section{Histochemical investigations}

\section{PAS-reaction for the general carbohydrates:}

The amount of muco-polysaccaride inclusion in the liver of control animals (Group I) that detected in the hepatocytes of normal rats noticed mainly in the form of strongly PAS reactive materials located mainly in the ground (Fig. 7A). The general polysaccharides distributions of PAS positive contents in $T$. granosa flesh body extract treatment (Group II) that was nearly similar to Group I (Fig. 7B). The hepatic tissues of Group III revealed a PAS positive contents that were markedly diminished in the hepatocytes compared to Group I (Fig. 7C). Meanwhile, in group received $\mathrm{KBr}$ plus T. granosa flesh body extract (Group IV), the PAS positive material has obviously nearly improvement of PAS intensity in the hepatic cells (Fig. 7D).

Mercury bromophenol blue (BPB) for total protein contents as bluish dark granules

The hepatocytes from control rats (Group I) that represented as intensive reaction and indicated by their characteristic bluish color (Fig. 7E). In liver tissues of T. granosa gavaged to rats (Group II), protein content which present in the cytoplasm of the hepatocytes noticed an intensive blue reaction as same as in normal liver. Clear protein content reduction was signed by the hepatic cells in $\mathrm{KBr}$ exposure rats (Fig. 7F). But, the peripheral zone of hepatocytes in Group (III) that showed vacuolated and most of the vacuolar areas were colorless. Also, a noticeable reduction of the protein contents in both nuclear as well as cellular membranes of the hepatocytes (Figs. $7 \mathrm{G}$ and $7 \mathrm{H})$. Rats received $\mathrm{KBr}$ plus T. granosa (Group IV) that visualized nearly retained the protein contents to their normal features (Fig. 7I). Also, repair demonstrated a clear restoration of the lost proteins which that found in hepatic strands (Fig. 7J).

\section{Chromosomal aberration assay}

In the present study, the statistical analyses of the total chromosomal aberrations for all the studied groups were illustrated in Tab. 2 and Fig. 8. We evaluated the chromosomal aberrations. In the Group I (control) and Group II (T. granosa flesh body extract) that showed healthy 

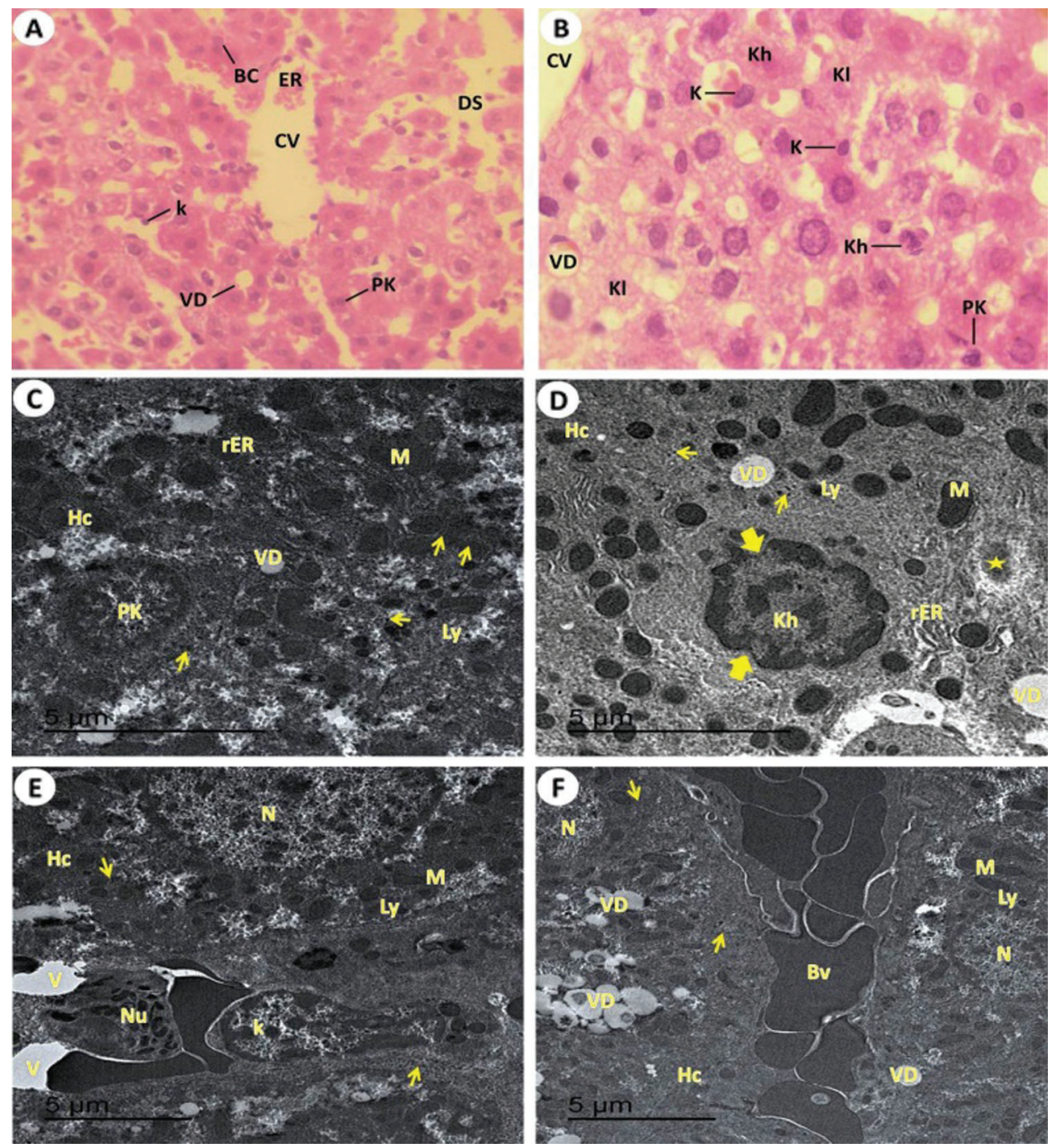

FIGURE 5. Light and electron investigations (A) Hepatic section by light microscope of rats which intoxicated with KBr (Group III) that shows Liver section by light microscope from potassium bromide induced rats displays the pyknotic cells ( $\mathrm{Pk}$ ) of liver, binucleated cells (BC) around the central vein (CV), vacuolar degeneration (VD), erosion of the endothelial which line the central hepatic vein (ER), numerous enlarged Kupffer cells (K) and dilated of the blood hepatic sinusoids (DS) (H.E., 400 X), (B) High enlargement of the previous liver section shows obvious vacuolar degeneration (VD), central vein (CV), pyknotic liver cell (Pk), karyorrhexis cell (Kh), karyolysis cell (Kl), numerous swollen of immune Kupffer cells vacuoles formation in the cytoplasm of hepatocytes and large dilated blood sinusoidal spaces and numerous Kupffer cells are swollen (H.E., $1000 \mathrm{X}$ ), (C) ultrastructure of hepatocytes (Hc) that pyknotic cell (PK), glycogen granules contents are decreased, numerous and large in size of lysosome, rough endoplasmic reticulum with tubular dilated, Golgi apparatus with dilated cisternae, numerous swollen of immune Kupffer cells, vacuoles formation in the cytoplasm of hepatocytes for formation vacuolar degeneration (VD), and large dilated blood sinusoidal spaces (10000 $\mathrm{X})$, (D) The damage of hepatocytes (Hc) with early stage of necrosis that shows karyorrhexis cell (Kh) with damage of nucleoplasm (thick arrow), dilated of rough endoplasmic reticulum (rER), swollen numerous of lysosomes (Ly), fibrous formation (star), damaged of mitochondria (M) and vacuolar degeneration (VD) (15000 X), (E) ultrastructure of hepatocytes (Hc), swollen of Kupffer cells (K) and neutrophils (Nu) are appeared $(15000 \mathrm{X})$ and $(\mathrm{F})$ shown the blood vessels are engorged with blood, formation of vascular degeneration (VD) and noticed down regulated of glycogen granules (arrows) (10000 X).

chromosomal rat was 42 normal intact chromosome without any aberration or disorder (Figs. 9A-9D). While, results of exposure of the experimental rats to $\mathrm{KBr}$ (Group III), the chromosomal aberrations were noticed as gap, break, deletion, fragments, polyploidy or chromosomal ring (Figs. 9E-9G). But, in Group IV (treated with T. granosa flesh body extract plus $\mathrm{KBr}$ ) that showed the restoration and appeared some chromosomal aberrations (Figs. 9H, 9I and 9J).

Chromosomes of rats which intoxicated with $\mathrm{KBr}$ (Group III) that displayed chromatid gap (G), deletion (DEL), double minute chromosomes (DMIN), chromatid break (cB), chromosomal ring (R), fragmentation (FR) and Polyploidy. $(\mathrm{H}$,
I and $\mathrm{J}$ ) chromosomes from $\mathrm{KBr}$ and $\mathrm{T}$. granosa body extract exposed that displayed and chromosomal ring (R), deletion (DEL), double minute chromosomes (DMIN), chromosomal break (CB), chromatid gap (G) and fragmentation (FR).

Effect on relative expression patterns of TGF- $\beta 1, V E G F$, and COX-2 genes

As depicted in Fig. 10, the mean mRNA expression of TGF- $\beta 1$ gene that was transcriped from liver tissues of rats was significantly upregulated in Group III (KBr) (4.277 fold) when compared to Group I (control), meanwhile the expression was significantly downregulated in Group IV (T. granosa plus 

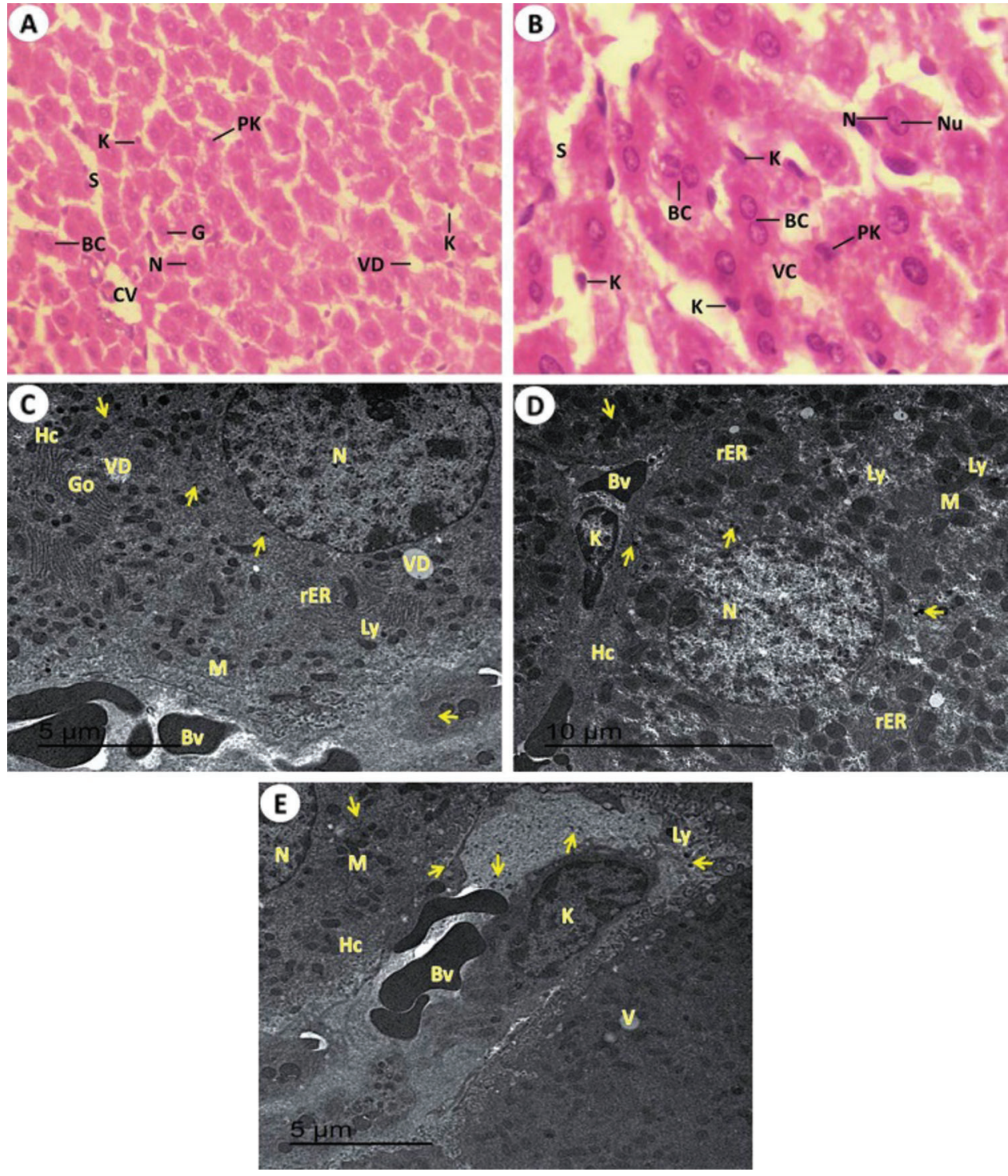

FIGURE 6. Light and electron investigations (A) Liver section by light microscope from rats received $\mathrm{KBr}$ plus $\mathrm{T}$. granosa flesh body extract (Group IV) that shows enhancement occur of some hepatocytes. Central vein $(\mathrm{CV})$, narrow hepatic sinusoids $(\mathrm{S})$, normal single or binucleated (BC) of nuclei $(\mathrm{N})$, pyknotic cells $(\mathrm{Pk})$ are reduced, Kupffer cells (K), vacuolar degeneration (VD) and giant cell (G) (H.E., $400 \mathrm{X}$ ), (B) High enlargement of the previous liver section represents some tissue improvement. The intact outline cords of hepatocytes with vacuolated cytoplasm (VC), normal single or binucleated (BC) of hepatocytes nuclei (N), nucleolus $(\mathrm{Nu})$, hepatic sinusoids (S) and some Kupffer cells $(\mathrm{K})$ are non-intact in numerous and appearance (H.E., 1000 $\mathrm{X}),(\mathrm{C}, \mathrm{D}$ and $\mathrm{E})$ ultrastructure of liver tissue detected that clear sign of ameliorative of $T$. granosa body extract in the repair in the hepatocytes (Hc) with normal euchromatic nucleus $(\mathrm{N})$, glycogen granules contents (arrows), lysosome (Ly), rough endoplasmic reticulum (rER), Golgi apparatus (Go), mitochondria $(\mathrm{M})$, Kupffer cells $(\mathrm{K})$, decrease in content of vacuolar degeneration (VD), narrow blood sinusoidal spaces and some of blood vessels are conjugated with blood (15000 X).
$\mathrm{KBr}$ ) (2.87 fold). On the other hand, the expression of TGF- $\beta 1$ gene was not significantly changed in Group II (T. granosa) when compared to Group I (1.88 fold). Similarly, the expression of VEGF gene exhibited a significant upregulation in Group III (KBr) (2.58 fold) when compared to Group I (control), On contrary to this result, the transcription of VEGF gene between Group II and Group IV displayed no significant alternations ( 0.280 fold and 0.68 fold, respectively) when compared to Group I. Additionally, the transcription of COX-2 gene was up-regulated in Group III in response to the administration of $(\mathrm{KBr})$ by six fold when compared to Group I, meanwhile, this upregulation was modulated by the use of T. granosa, the expression of COX2 was downregulated significantly in Group IV (T. granosa plus $\mathrm{KBrO} 3$ ) (1.98 fold). Also, this trend was identified in Group II (T. granosa) as the expression of COX-2 was downregulated significantly ( 0.96 fold) in comparison to Group I.

\section{Discussion}

The aim of this study was to discover the protective effect of Tegillarca granosa flesh body extract against $\mathrm{KBr}$ hepatotoxicity. Important reductions in serum levels of hepatic damage indices like TAC, as well as CAT and GST enzymes, demonstrate the effect of $\mathrm{KBr}$. Furthermore, administration of Tegillarca granosa flesh body extract resulted in a substantial improvement in hepatic antioxidant safety, as well as significant reductions in antioxidant content and DNA damage caused by $\mathrm{KBr}$ exposure. All of these biochemical improvements were backed up by significant histopathological improvements and clear regulation of changes in the chromosomal aberration assay and target gene expression levels. After oxidative damage to DNA, potassium bromate $(\mathrm{KBrO} 3)$ mediated ROS and NOS were found to cause chromosomal aberration, DNA adducts formation, and generation of $8-\mathrm{OH} \mathrm{dG}$ (de Angelo et al., 2016). As a result, the compound directly or indirectly interferes with or compromises the biological effectiveness of many essential proteins and related macromolecules, disrupting many cellular functions (Hassan et al., 2019). The results are consistent with our own (Ahmed and Mahmood, 2012). They discovered that giving rats $\mathrm{KBrO} 3$ caused oxidative stress and reduced antioxidant strength. During its biotransformation, it could produce toxic effects in vivo model studies by producing reactive oxygen species, which triggered cellular redox balance and structural integrity in target tissues (Tahir et al., 2013). It is a potent oxidant that 

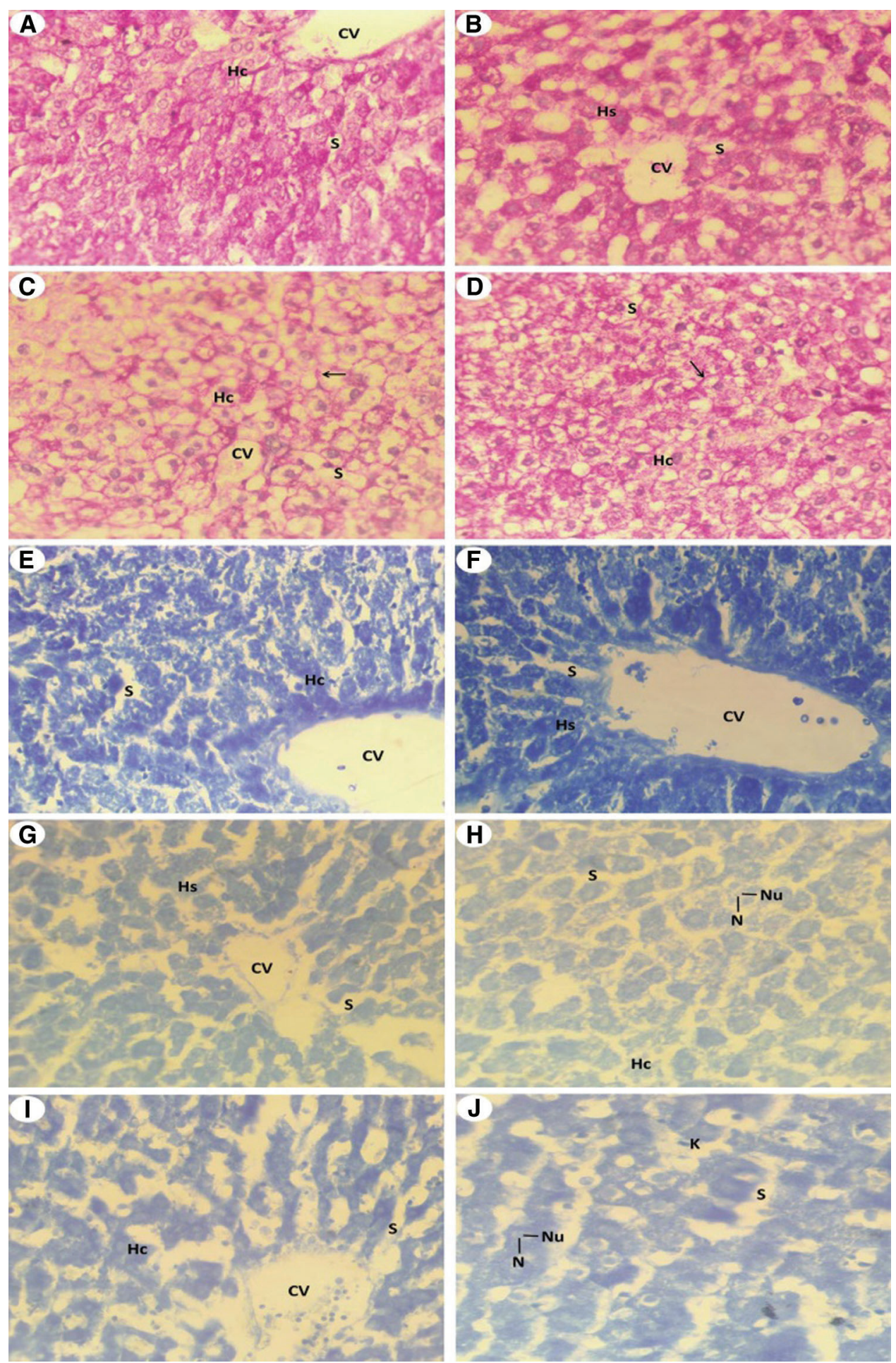

FIGURE 7. Light investigations for histochemistry studies (A) Liver section by light microscope from Group I (control) that showed strong PAS positive materials. Intensity of magenta color which detecting PAS positive reaction in the liver cells of intact control rat, central vein (CV) which surrounding by hepatic strands (Hs) and hepatic sinusoidal space (S) (PAS, $400 \mathrm{X}$ ), (B) Liver section from rat liver received T. granosa flesh body extract (Group II) that detected intensive reaction of PAS similar to Group I (PAS, $400 \mathrm{X}$ ), (C) Liver section from rat which intoxicated with $\mathrm{KBr}$ (Group III) that showed downregulated of PAS concentrations and glycogen flight (arrow) within the hepatic cell (Hc) and hepatic blood sinusoidal space (S) (PAS, $400 \mathrm{X}$ ), (D) Liver section from rat which exposed to $\mathrm{KBr}$ and T. granosa flesh body extract (Group IV) that detected sign degree of repair in glycogen flight (arrow) within the hepatocyte (Hc) and hepatic blood sinusoidal space (S) (PAS, $400 \mathrm{X})$, (E) Liver section of control rats (Group I) that detected normal forms and severe reaction for proteins inclusions of the hepatocytes that represented by dark blue granules. Central vein (CV), hepatocytes (Hc), hepatic blood sinusoid (S) (BPB, $400 \mathrm{X})$, (F) Liver section of T. granosa treated rats (Group II) that showed nearly normal inclusion of proteins that similar to control healthy group (BPB, $400 \mathrm{X}$ ), (G) Liver section from $\mathrm{KBr}$ induced rats (Group III) that displayed significant reduction of protein contents in the hepatic strands (Hs). Central vein (CV), nucleus (N) and hepatic blood sinusoidal (S) are found (BPB, $400 \mathrm{X}),(\mathrm{H})$ Enlarged Part of the liver section of Group III that showed reduced of protein stained materials in the hepatic cells $(\mathrm{Hc})$, hepatic blood sinusoid $(\mathrm{S})$, nucleus $(\mathrm{N})$ and nucleolus $(\mathrm{Nu})$ are visualized $(\mathrm{BPB}, 1000 \mathrm{X})$, (I) Liver section from rat which received of $\mathrm{KBr}$ plus T. granosa (Group IV) that detected restoration of protein reaction in the most of hepatic cells (Hc), central vein (CV) and hepatic blood sinusoid (S) are showed (BPB, $250 \mathrm{X}$ ) and (J) Enlarged the previous liver section by light microscope from treated rats that displayed some restoration of protein stained materials in some hepatocytes of Group IV, some hepatocytes still showing reduced amount of proteins and some clear sign of restoration (BPB, $1000 \mathrm{X})$. 
TABLE 2

The chromosomal aberrations for different experimental groups

\begin{tabular}{|c|c|c|c|c|c|c|c|c|}
\hline \multirow[b]{2}{*}{$\begin{array}{l}\text { Experimental } \\
\text { groups }\end{array}$} & \multicolumn{8}{|c|}{ Chromosomal Aberrations } \\
\hline & $\begin{array}{l}\text { Chromatid } \\
\text { Gap }\end{array}$ & $\begin{array}{l}\text { Chromatid } \\
\text { Break }\end{array}$ & $\begin{array}{l}\text { Chromosomal } \\
\text { break }\end{array}$ & Deletion & Fragmentation & $\begin{array}{l}\text { Chromosomal } \\
\text { ring }\end{array}$ & $\begin{array}{l}\text { Double } \\
\text { minute } \\
\text { chromosomes }\end{array}$ & Polyploidy \\
\hline $\begin{array}{l}\text { Control } \\
\text { (Group I) }\end{array}$ & 3.00 & 5.50 & 5.50 & 3.00 & 5.50 & 8.00 & 5.50 & 3.40 \\
\hline $\begin{array}{l}\text { T.granosa } \\
\text { (Group II) }\end{array}$ & 8.00 & 5.50 & 5.50 & 8.00 & 5.50 & 3.00 & 5.50 & 7.60 \\
\hline KBr (Group III) & 18.00 & 16.70 & 18.00 & 18.00 & 18.00 & 18.00 & 18.00 & 18.00 \\
\hline $\begin{array}{l}\text { KBr plus } \\
\text { T.granosa } \\
\text { (Group IV) }\end{array}$ & 13.00 & 14.30 & 13.00 & 13.00 & 13.00 & 13.00 & 13.00 & 13.00 \\
\hline Chi-square & 17.938 & 16.808 & 18.379 & 17.992 & 18.427 & 17.871 & 18.363 & 17.358 \\
\hline$P$ value & 0.000 & 0.000 & 0.000 & 0.000 & 0.000 & 0.000 & 0.000 & 0.000 \\
\hline
\end{tabular}

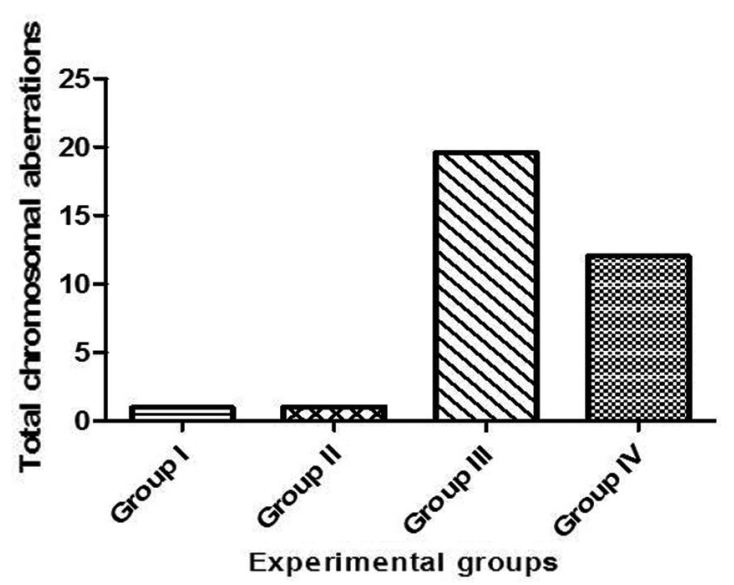

FIGURE 8. Total chromosomal aberration for experimental groups.

irritates reactive oxygen species (ROS), causing lipid peroxidation and lowering GSH levels (De Angelo et al., 2016). A substantial decrease in CAT activity was also observed after the administration of $\mathrm{KBrO} 3$ (Edwards and Fuller, 1996). Another analysis in mice treated with bromate revealed low levels of CAT activity (Ali and Al-Firdous, 2012). In line with our findings, a study was conducted in male rats that were injected with a single dose of $\mathrm{KBrO} 3$, and the function of the CAT enzyme was reduced (Wahba and Ibrahim, 2013).

(Kujawska et al., 2013) discovered that a single intraperitoneal injection of $\mathrm{KBrO} 3$ in rats may increase the activity of antioxidant GST enzyme in hepatic cells by ROS inhibition of GSH synthesis. GSH levels were also found to be significantly higher in the kidneys of rats given the same dose of $\mathrm{KBrO}$. It was most likely a physiological reaction to compensate for a drop in cellular GSH (Giri et al., 1999). Reduced GSH may be used as a marker of a cell's hepatoreactivity, and its lower activities indicate that lipid peroxidation is promoted, resulting in tissue damage and a failure of the body's antioxidant protection mechanisms to prevent the development of excessive free radicals (Bayomy et al., 2016). Bromate has also been suggested to form reactive genotoxic radicals $(\mathrm{Br}, \mathrm{BrO}$, and $\mathrm{BrO} 2)$ in reaction with reduced GSH and other thiols rather than directly reacting with DNA (Chipman et al., 2006).

Damage to the liver tissues was caused by a high dose of potassium bromide $(\mathrm{KBr})$ at the cellular and nuclear levels, including damage to hepatocords and hepatocytes, necrotic stages such as pyknosis, karyohexis, and karyolysis, multiple and large lysosomes, and swollen and numerous immune Kupffer cells. The target cells' cell membrane and membranous organelles (mitochondria, lysosomes, Golgi bodies, and endoplasmic reticulum) are further invaded by these violent radicals. The carbohydrate and total protein contents in the cytoplasm of hepatic cells are also reduced by this toxicity.

$\mathrm{KBrO} 3$ is extremely toxic to tissues (Ajarem et al., 2016). It affects macromolecules' biological activity (proteins, enzymes, lipids, and carbohydrates), resulting in substantial tissue damage and cellular dysfunction (Starek and Starek-Świechowicz, 2016). Furthermore, necrosis and apoptosis have been identified as a result of a high dose or after an extended period of $\mathrm{KBrO} 3$ administration (Bayomy et al., 2016). Furthermore, biotransformed $\mathrm{KBrO} 3$ produces hyperactive metabolites (bromate and bromide radicals) that are extremely damaging to cellular macromolecules and structure (Kawana et al., 1991).

$\mathrm{KBr}$ caused large increases in the frequencies of chromosomal aberrations such as chromatid distance, deletion, double minute chromosomes, chromatid split, chromosomal ring, and fragmentation, according to genetic analysis. These results were identical to those previously published (Kaya and Topaktaş, 2007; Speit et al., 1999; Starek and Starek-Świechowicz, 2016). Bromate-induced oxidative stress has been proposed to play a role in its genotoxicity through a lysosome damage mechanism that occurs before oxidative DNA damage (Zhang et al., 2011). Furthermore, oral administration of $\mathrm{KBrO} 3$ to rats resulted in DNA damage, as evidenced by an increase in the frequency of chromosomal abnormalities, the formation of micronuclei, and the percentage of DNA fragmentation (Abd El-Rahim et al., 2018). The interaction of DNA with ROS, which may be caused by the use of $\mathrm{KBr}$, has been 

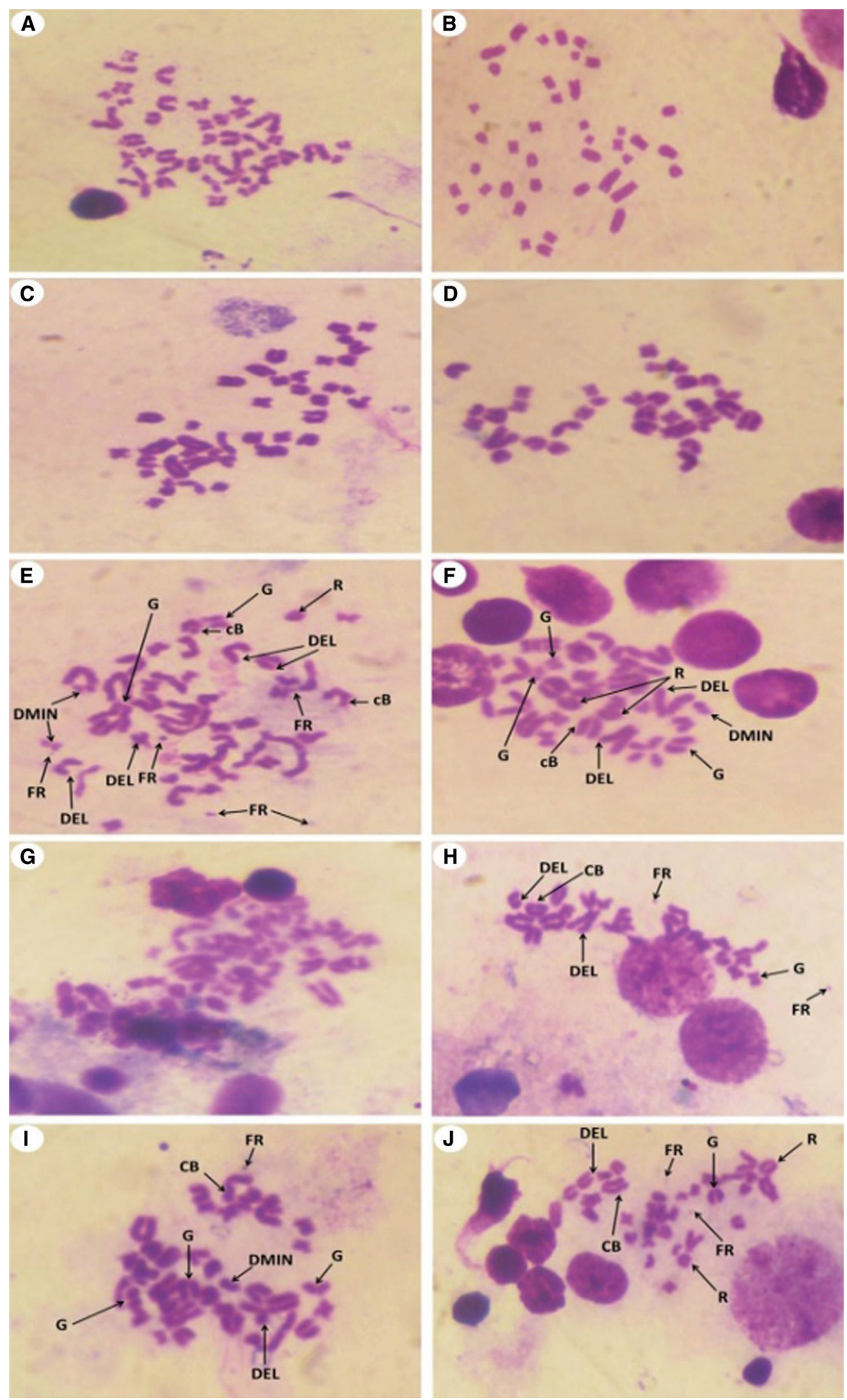

FIGURE 9. Metaphase spread of different experimental rats from bone marrow cells of femur bone (Giemsa, $1500 \mathrm{X}$ ) that showed the following; (A and B): Normal (Group I) detected 42 normal chromosomes. (C and D) Normal chromosomes from rats received $T$. granosa flesh body that extract (Group II) that similar to Group I. (E, $\mathrm{F}$ and $\mathrm{G})$. ( $\mathrm{H}, \mathrm{I}$ and $\mathrm{J})$ chromosomes from $\mathrm{KBr}$ and $\mathrm{T}$. granosa body extract exposed that displayed and chromosomal ring (R), deletion (DEL), double minute chromosomes (DMIN), chromosomal break (CB), chromatid gap $(\mathrm{G})$ and fragmentation (FR).

established. The hydroxyl radical, in particular, causes various modifications in DNA, resulting in strand breaks and the release of free bases from nucleic acid (Murata et al., 2001). Bromine oxides and radicals also induced DNA oxidation, which resulted in DNA damage. As a result, $\mathrm{KBrO3}$ induced micronuclei in mice and rats' peripheral blood reticulocytes (Awogi et al., 1992; Sai et al., 1992), as well as cells in the glandular portion of the stomach and liver (Okada et al., 2015).
TGF-1 gene expression was significantly upregulated in Group III ( $\mathrm{KBr})$ in this context, demonstrating $\mathrm{KBr}$ toxicity. Meanwhile, the expression was substantially downregulated in Groups II and III, indicating that T. granosa flesh body extract has a protective effect. TGF-1 can bind to Type II TGF-b receptors, causing type II receptors to convert to Type I TGF-b receptors and phosphorylate them. The activation of TGF-b signaling has been linked to the 
A

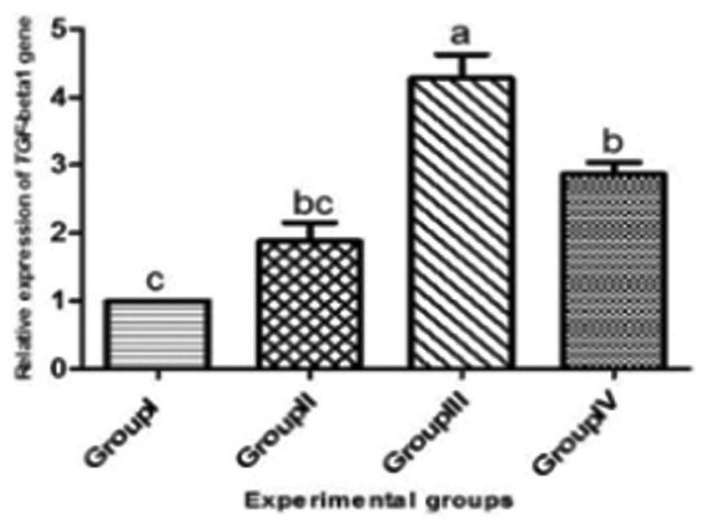

C

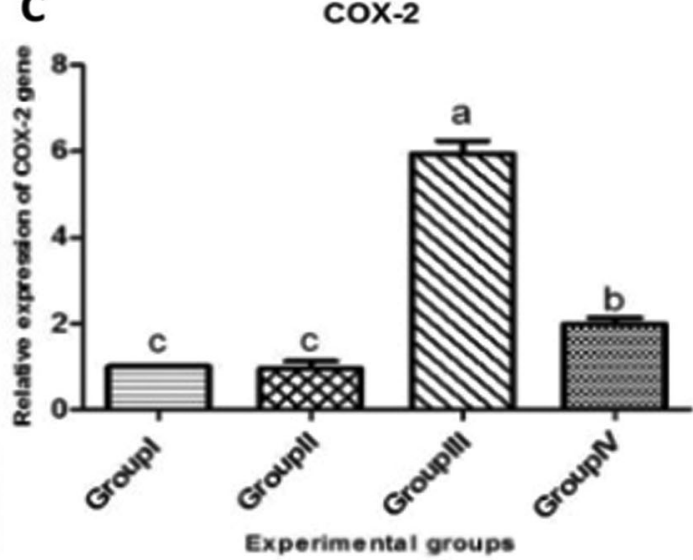

B

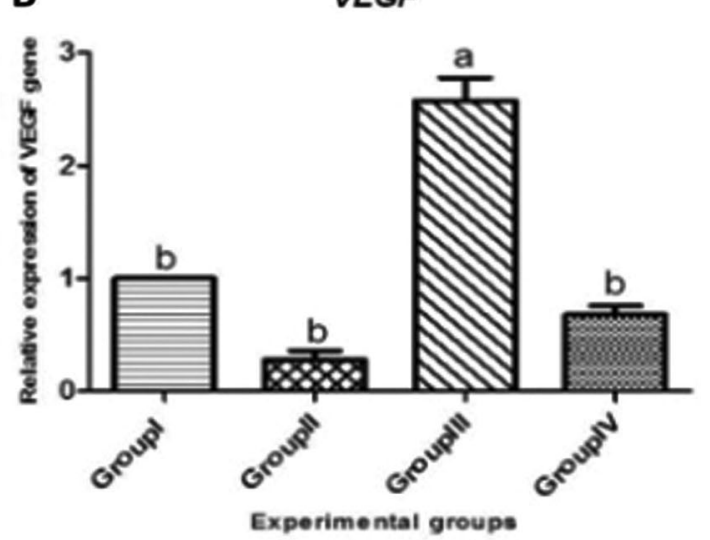

cox-2

FIGURE 10. Relative expressions of TGF-beta 1 (A), VEGF (B) and COX-2 (C) genes in the liver tissue of male albino rats that orally gavaged with $\mathrm{KBr}(150 \mathrm{mg} / \mathrm{kg}$ bwt $)$ day after day and they were treated orally with $T$. granosa flesh body extract ( $200 \mathrm{mg} / \mathrm{kg}$ bwt) day after day. Values are presented as mean \pm SEM $(n=10)$. Values are expressed as (mean \pm SE), differ significantly at $p<0.05$ by one-way ANOVA followed by Duncan post hoc test.

development of fibrosis in the liver (Gressner et al., 2002). TGF activation is recognized as a regulator of chronic liver disease, initiating all stages of disease progression from initial liver injury through inflammation and fibrosis to cirrhosis, according to the findings of our research. In this regard, hepatic cell activation through TGF-b signaling is linked to fibrogenic response (Dooley and Dijke, 2012). TGF-1 regulates hepatic fibrosis via intracellular signal transduction pathways, and TGF-1 substrate is the only family that has been identified (Yao and $\mathrm{Xu}, 2003$ ). They confirmed the upregulation of TGF-b expression in patients with liver fibrosis, similar to our findings (Cayon et al., 2006; Klein et al., 2006). A research was conducted to determine if TGF-b gene signaling in hepatocytes promoted hepatocyte damage and fibrosis (Yang et al., 2013). It also induced the formation of reactive oxygen species (ROS) and the death of lipid-accumulating hepatocytes, with a positive association between serum TGF-1 levels and the developmental stage of liver fibrosis (Clemente et al., 2006) and the severity of liver fibrosis (Abbass et al., 2011).

We discovered a cross-talk between VEGF and VEGFR in this context; there are two forms of tyrosine kinase receptors, VEGFR-1 and VEGFR-2 (Shibuya, 2001). Our findings are consistent with those who discovered a major upregulation of the VEGF gene during the production of liver fibrosis in an experimental study (Torimura et al., 1999; Corpechot et al., 2002), and that VEGF led to sinusoidal capillarisation in the liver. The findings also revealed that after intoxication with hepatotoxic content, the VEGF gene was upregulated in the rat's hepatic tissues. Meanwhile, (Rosmorduc et al., 1999), an attempt was made to understand the reasons for VEGF expression in the liver and its connection to chronic liver disease (Ishikawa et al., 1999). The VEGF gene was found to be upregulated in the cirrhotic liver, indicating that it plays a role in cirrhosis-related angiogenesis (El-Assal et al., 1998). The theory revealed that it promotes the proliferation of liver stellate cells and sinusoidal endothelial cells, which leads to the production of liver fibrosis (Geerts et al., 2006; Jerzy et al., 2008).

COX-2 gene expression was significantly upregulated in Group III (KBr) when compared to Group I (control group), indicating the toxicity of this compound, and significantly downregulated in Group IV ( $\mathrm{KBr}$ plus Tegillarca granosa) when compared to Group I (control group), indicating the toxicity of this compound (control). Meanwhile, inflammatory mediators may be responsible for COX-2 speech. COX-2 expression was found to play a key role in inflammation and tumorigenesis in previous studies (Smith et al., 2000). Its expression was found to be higher during chronic hepatic tissue inflammation and the early stages of hepatocarcinogenesis (Koga et al., 1999; Yu et al., 2007). In a 
rat model of acute and chronic liver injury, the expression of COX-2 gene was increased by about 15 fold as compared to normal hepatic tissues (Wójcik et al., 2012), which is consistent with our findings. Its expression has also been found in rats with alcoholic liver disease (Nanji et al., 1994). Furthermore, our findings are consistent with those of (Yu et al., 2007), who reported that COX-2 gene expression was not detected in normal liver but was detected in chronic inflammatory hepatic tissue. COX-2 overexpression was found to play a key role in the production of hepatocellular carcinoma (Koga et al., 1999; Chen et al., 2017).

Treatment with Tegillarca granosa flesh body extract, on the other hand, improved the structure of liver cells as well as their carbohydrate and total protein contents. This is the first research to show that this extract has hepatoprotective properties. T. granosa extract has potent hepatoprotective and antioxidant properties, particularly when given prior to and concurrently with $\mathrm{KBr}$ care. These effects were observed in Groups II and IV, and they were followed by changes in serum antioxidant biochemical markers, suggesting that this extract could prevent these biomarkers from increasing (TAC, CAT and GST), Hepatic ultrastructure, histochemical modifications, frequency of chromosomal aberrations, and alternation of TGF-1, VEGF, and COX-2 genes upregulation all showed progress. The antioxidant properties of $T$. granosa have been discovered, as it is capable of scavenging free radicals and inhibiting lipid peroxidation (Yang et al., 2019). Multiple antioxidative peptides isolated and recognized from protein extracts of T. granosa muscle (Chi et al., 2015; Yang et al., 2019) were also found to support T. granosa's protective function. This may be due to the abundance of free amino acids such as taurine, glycine, and arginine (Kim et al., 2002).

These free amino acids have also been identified as a nutrient source for improving endothelial function (Kamada et al., 2001; Khadieva et al., 2019). Taurine is thought to be the most nutritive amino acid found in T. granosa, and it has an endothelial defensive effect by restoring redox homeostasis. $T$. granosa polysaccharides are thought to have iron chelating and radical scavenging properties (Qiao et al., 2009).

The high content of free amino acids in T. granosa extract, such as glutamic acid, glycine, and L-arginine, has been shown to increase vascular endothelial reactivity in rats (Chanmuang et al., 2020). Minerals and betaine, which are found in $T$. granosa, can contribute to the prevention effects (Park, 2002, Nguyen et al., 2017). Betaines convert homocysteine, which has negative effects on endothelial activity, to methionine, which acts as a methyl donor (Park, 2002; Esse et al., 2019). Docosahexaenoic acid and eicosapentaenoic acid are two other components of $T$. granosa that have antioxidant properties (Grienke et al., 2014).

\section{Conclusion}

This study was designed in order to show the hepatotoxic effect of potassium bromide $(\mathrm{KBr})$ and also, it spot light on the protective role of Tegillarca granosa against this toxicity. The main consequence of this context is that potassium bromide orally induces significant oxidative damage and injury to the liver via modifying the biochemical, histopathological, histochemical and genetic indices under investigation including: chromosomal aberration and expression pattern of target genes including TGF- $\beta 1$, VEGF and COX-2 genes.

Acknowledgement: The authors would like to thank the Deanship of Scientific Research at Taif University for funding this work through Taif University Researchers Supporting Project No. (TURSP-2020/222), Taif University, Taif, Saudi Arabia.

Author Contributions: Conceptualization, A. A.; B. H. and Y. M. A.; methodology, A. A; B. H.; E. F.; F. A. and Y. M. A. software; validation, formal analysis; investigation.; resources.; data curation,; writing-original draft preparation; writing-review and editing; visualization; E. F.; F. A. project administration; funding acquisition. All authors have read and agreed to the published version of the manuscript.

Data Availability Statement: The data generated or investigated during this study are obtainable from the corresponding author on reasonable request.

Institutional Review Board Statement: This study was performed according to the guidelines of the US National Institute of Health (NIH Publication No. 85.23, revised 1985) guides for the care of laboratory animals.

Funding Statement: This study was funded by Taif University Researchers Supporting Project No. (TURSP-2020/222), Taif University, Taif, Saudi Arabia.

Conflicts of Interest: The authors declare that they have no conflicts of interest to report regarding the present study.

\section{References}

Abbass S, Hendawy G, El Taher SM, Younis F, Ali ST et al. (2011). Role of hepatic transforming growth factor- $\beta 1$ (tgf- $\beta 1$ ) and serum hyaluronic acid in the pathogenesis of liver fibrosis in chronic HCV patients. Azhar Assiut Medical Journal 9: $1-12$.

Abd El-Aziz YM, Abu Almaaty AH, Omar NA, Abdeen AM, Zakaria MM (2019). Evaluation of protective effects of propolis against aluminium silicate toxicity in rats. Genetika 51: 299-312.

Abd El-Rahim AH, Abd-El-Moneim OM, Abd El-Kader MHA, Abd El Raouf A (2018). Inhibitory effect of bee venom against against potassium bromate causing genetic toxicity and biochemical tions in alternations mice. Journal of the Arab Society for Medical Research 13: 89-98.

Achyut BR, Yang L (2011). Transforming growth factor-beta in the gastrointestinal and hepatic tumor microenvironment. Gastroenterology 141: 1167-1178.

Ahmad M, Khan A, Mahmood R (2012). Alterations in brush border membrane enzymes, carbohydrate metabolism and oxidative damage to rat intestine by potassium bromate. Biochimie 94: 2776-2782.

Ahmed MK, Mahmood R (2012). Oral administration of potassium bromate, a major water disinfection byproduct, induces oxidative stress and impairs the antioxidant power of rat blood. Chemosphere 87: 750-756.

Ajarem J, Altoom NG, Allam AA, Maodaa SN, Abdel-Maksoud MA, Billy CKC (2016). Oral administration of potassium bromate 
induces neurobehavioral changes, alters cerebral neurotransmitters level and impairs brain tissue of swiss mice. Behavioral and Brain Functions 12: 12-14.

Alexander de Lahunta, Eric Glass (2009). Seizure disorders: Narcolepsy. In: Veterinary Neuroanatomy and Clinical Neurology, 3rd Edition, pp. 454-475. Saunders.

Ali W, Al-Firdous FA (2012). Effect of consumption of kiwi fruit on potassium bromate induced oxidative stress in rats. Australian Journal of Basic and Applied Sciences 6: 519-524.

Anusha SC, Sini H, Prakashkumar B, Nevin GK (2019). Mechanism of protection of rat hepatocytes from acetaminopheninduced cellular damage by ethanol extract of Aerva lanata. Interdisciplinary Toxicology 12: 169-179.

Awogi T, Murata K, Uejima M, Kuwahara T, Asanami S, Shimono K, Morita T (1992). Induction of micronucleated reticulocytes by potassium bromate and potassium chromate in CD-1 male mice. Mutation Research 278: 181-185.

Bagley RS, Chen AV (2013). Anticonvulsants. Small Animal Toxicology. Third Edition. Elsevier, Canada.

Bancroft JD, Gamble M (2008). Theory and Practice of Histological Techniques. Elsevier Health Sciences.

Bayomy AN, Soliman GM, Abdelaziz EZ (2016). Effect of potassium bromate on the liver of adult male albino rat and a possible protective role of vitamin C: Histological, immunohistochemical, and biochemical study. Anatomical Record 299: 1256-1269.

Blair RC (1981). A reaction to conseluences of failure to meet assumptions underlying the fixed effects analysis of variance and covariance. Review of Educational Research 51: 499-504.

Cayon A, Crespo J, Mayorga M, Guerra A, Pons-Romero F (2006). Increased expression of $\mathrm{Ob}-\mathrm{Rb}$ and its relationship with the overexpression of TGF-betal and the stage of fibrosis in patients with nonalcoholic steatohepatitis. Liver International 26: 1065-1071.

Chanmuang S, Meemalai O, Promyo K, Park KH, Pongworn S, Gong DS, Oak MH, Cho JY, Kang SG, Ham KS (2020). Ameliorative effects of ark clams (Scapharca subcrenata and Tegillarca granosa) on endothelial dysfunction induced by a high-fat diet. Applied Biological Chemistry 63: 1-7.

Chen H, Cai W, Chu HES, Tang J, Wong CC et al. (2017). Hepatic cyclooxygenase-2 overexpression induced spontaneous hepatocellular carcinoma formation in mice. Oncogene 36: 4415-4426.

Chi CF, Hu FY, Wang B, Tao L, Ding GF (2015). Antioxidant and anticancer peptides from the protein hydrolysate of blood clam (Tegillarca granosa) muscle. Journal of Functional Foods 15: 301-313.

Chipman JK, Parsons JL, Beddowes EJ (2006). Themultiple influences of glutathione on bromate genotoxicity: implications for the doseresponse relationship. Toxicology 221: 187-189.

Clemente M, Nunenz O, Lorente R, Rincon D, Matilla A et al. (2006). Intrahepatic and circulating levels of endoglin, a TGF- $\beta 1$ coreceptor, in patients with chronic hepatitis $\mathrm{C}$ virus infection: relationship to histological and serum markers of hepatic fibrosis. Journal of Viral Hepatitis 13: 625-632.

Corpechot C, Barbu V, Wendum D (2002). Hypoxia-induced VEGF and collagen I expressions are associated with angiogenesis and fibrogenesis in experimental cirrhosis. Hepatology 35: 1010-1021.

De Angelo AB, George MH, Kilburn SR, Moore TM, Wolf DC (2016). Carcinogenicity of potassium bromate administered in the drinking water to male B6C3F1Mice and F344/N rats. Toxicologic Pathology 26: 587-594.

Dooley S, Dijke PT (2012). TGF-beta in progression of liver disease. Cell Tissue Research 347: 245-256.

Edwards CJ, Fuller J (1996). Oxidative stress in erythrocytes. Comparative Haematology International 6: 24-31.

El-Assal ON, Yamanoi A, Soda Y, Yamaguchi M, Igarashi M et al. (1998). Clinical significance of microvessel density and vascular endothelial growth factor expression in hepatocellular carcinoma and surrounding liver: Possible involvement of vascular endothelial growth factor in the angiogenesis of cirrhotic liver. Hepatology 27: 1554-1562.

Esse R, Barroso M, Tavares DAI, Castro R (2019). The contribution of homocysteine metabolism disruption to endothelial dysfunction: State-of-the-Art. International Journal of Molecular Sciences 20: 867.

Finkel T, Holbrook NJ (2000). Oxidants, oxidative stress and the biology of ageing. Nature 408: 239-247.

Friedman SL (2008). Mechanisms of hepatic fibrogenesis. Gastroenterology 134: 1655-1669.

Geerts AM, de Vriese AS, Vanheule E, van Vlierberghe H, Mortier S et al. (2006). Increased angiogenesis and permeability in the mesenteric microvasculature of rats with cirrhosis and portal hypertension: An in vivo study. Liver International 26: 889-898.

Gerber HP, Hillan KJ, Ryan AM, Kowalski J, Keller GA et al. (1999). VEGF is required for growth and survival in neonatal mice. Development 126: 1149-1159.

Gibbs RA (2004). Genome sequence of the Brown Nor way rat yields insights into mammalian evolution. Nature 428: 493-521.

Giri U, Iqbal M, Athar M (1999). Potassium bromate (KBrO3) induces renal proliferative response and damage by elaborating oxidative stress. Cancer Letters 135: 181-188.

Gressner AM, Weiskirchen R, Breitkopf K, Dooley S (2002). Roles of TGF beta in hepatic fibrosis. Frontiers in Bioscience 7: d793-d807.

Grienke U, Silke J, Tasdemir D (2014). Bioactive compounds from marine mussels and their effects on human health. Food Chemistry 142: 48-60.

Guo XS, Li Y (2003). Marine Chinese Traditional Medicines, pp. 138141. Beijing: Sciences Press.

Hassan I, Ebaid H, Alhazza IM, Al-Tamimi J, Aman S, AbdelMageed AM (2019). Copper mediates anti-inflammatory and antifibrotic activity of gleevec in hepatocellular carcinoma-induced male rats. Canadian Journal of Gastroenterology \& Hepatology 9897315: 1-11.

He JJ, Li Y, Li TW, Su XR, Wang MQ et al. (2009). Construction of cDNA library with Tegillarca granosa muscular tissue and sequence analysis of Ferritin gene. Journal of Oceanology and Limnology 40: 289-295.

Ibrahim RM, Allam MM, El-Gohary OA, El-Talees AAE, El-Hamady MS (2018). Protective effect of obestatin on indomethacininduced acute gastric ulcer in rats: role of VEGF and TNF-a. Benha Medical Journal 35: 369-377.

Ishikawa K, Mochida S, Mashiba S, Inao M, Matsui A et al. (1999). Expressions of vascular endothelial growth factor in nonparenchymal as well as parenchymal cells in rat liver after necrosis. Biochemical and Biophysical Research Communications 254: 587-593.

Jennifer LD (2018). Pharmacologic principles. In: Equine Internal Medicine, 4th edition, pp. 79-137. Elsevier.

Jerzy J, Marcin J, Robert F, Magdalena R, Alicja K, Iwona W (2008). Circulating vascular endothelial growth factor and its soluble 
receptors in patients with liver cirrhosis: possible association with hepatic function impairment. Cytokin 44: 14-17.

Kamada Y, Nagaretani H, Tamura S, Ohama T, Maruyama T et al. (2001). Vascular endothelial dysfunction resulting from Larginine deficiency in a patient with lysinuric protein intolerance. Journal Clinical Invest 108: 717-724.

Karkkainen MJ, Petrova TV (2000). Vascular endothelial growth factor receptors in the regulation of angiogenesis and lymphangiogenesis. Oncogene 19: 5598-5605.

Karnovsky MJ (1965). A formaldehyde -glutaraldehyde fixative of high osmolality for use in electron microscopy. Journal of Cell Biology 27: 137-138.

Kawana K, Nakaoka T, Horiguchi Y, Watanabe S, Watanabe S, Kawauchi S (1991). Toxicological study of potassium bromate. I. Absorption, metabolism and excretion of potassium bromate after oral administration in rats. Eisei Kagaku-Japanese Journal of Toxicology and Environmental Health 37: 258-265.

Kaya FF, Topaktaş M (2007). Genotoxic effects of potassium bromate on human peripheral lymphocytes in vitro. Mutation Research 626: 48-52.

Khadieva TA, Pokrovskaya TG, Belousova YV (2019). Pharmacological correction of endothelial dysfunction using ademethionin and taurine. Research Results Pharmacol 5: 13-21.

Kim KS, Lim JJ, Bae TJ, Park CK, Kim MH (2002). Characteristic of food components in granular ark and ark shell. Journal Korean Fish Society 35: 512-518.

Klein S, Mittendorfer B, Eagon JC, Patterson B, Grant L et al. (2006). Gastric bypass surgery improves metabolic and hepatic abnormalities associated with nonalcoholic fatty liver disease. Gastroenterology 130: 1564-1572.

Koga H, Sakisaka S, Ohishi M, Kawaguchi T, Taniguchi E et al. (1999). Expression of cyclooxygenase-2 in human hepatocellular carcinoma: Relevance to tumor dedifferentiation. Hepatology 29: 688-696.

Kujawska M, Ignatowicz E, Ewertowska M, Adamska T, Markowski J, Liebert JJ (2013). Attenuation of $\mathrm{KBrO} 3$ induced renal and hepatic toxicity by cloudy apple juice in rat. Phytotherapy Research 27: 1214-1219.

Lee YS, Choi JY, Patrk MK, Choi EM, Kasai H et al. (1996). Induction of OH8Gua glycosylase in rat kidneys by potassium bromate (KBrO3), a renal oxidative carcinogen. Mutation Research 364: $227-233$.

Livak KJ, Schmittgen TD (2001). Analysis of relative gene expression data using real-time quantitative PCR and the 2_DDCt method. Methods 25: 402-408.

Lorenz MD, Coates J, Kent M (2011). Handbook of Veterinary Neurology (5th edition). Elsevier, Canada.

Makanya AN, Djonov V, Hlushchuk R (2011). Escape mechanisms after antiangiogenic treatment, or why are the tumors growing again? International Journal of Developmental Biology 55: 563-567.

McCord JM (2000). The evolution of free radicals and oxidative stress. American Journal of Medicine 108: 652-659.

Meade EA, Smith WL, DeWitt DL (1993). Differential inhibition of prostaglandin endoperoxide synthase (cyclooxygenase) isozymes by aspirin and other non-steroidal anti-inflammatory drugs. Journal of Biological Chemistry 268: 6610-6617.

Murata M, Bansho Y, Inoue S, Ito K, Ohnishi S, Midorikawa K, Kawanashi $S$ (2001). Requirement of glutathione and cysteine in guaninespecific oxidation of DNA by carcinogenic potassium bromated. Chemical Research in Toxicology 14: 678-685.
Nanji AA, Khwaja S, Tahan SR, Sadrzadeh SMH (1994). Plasma levels of a novel non cyclooxygenase-derived prostanoid (8isoprostane) correlate with severity of liver injury in experimental alcoholic liver disease. Journal of Pharmacology and Experimental Therapeutics 269: 1280-1285.

Nguyen T, Rohmah Z (2017). Antioxidant activities in processed cockle (Tegillarca granosa) from the Yeosu. Journal of Agriculture and Life Sciences 51: 131-138.

Nguyen TT, Choi YJ, Rohmah Z, Jeong SB, Hwang DJ et al. (2017). Seasonal variations of nutritional components in cockles (Tegillarca granosa) processed from the Southern Coast of Korea. Cogent Food \& Agriculture 3: 1360102.

Novo E, Parola M (2008). Redox mechanisms in hepatic chronic wound healing and fibrogenesis. Fibrog Tissue Repair 13: 5-23.

Okada E, Fujiishi Y, Narumi K, Kado S, Wako Y et al. (2015). Evaluation of repeated dose micronucleus assays of the liver and gastrointestinal tract using potassium bromate: A report of the collaborative study by CSGMT/JEMS. MMS. Mutation Research 780: 94-99.

Park CK (2002). Comparison of extractive nitrogenous constituents in the Three Species of raw bloody clams, Scaphrca broughtonii, S. subcrenata, and Tegillarca granosa Extracts. Korean Journal of Food Science Technology 34: 954-961.

Pasche B (2001). Role of transforming growth factor beta in cancer. Journal of Cellular Physiology 186: 153-168.

Promyo K, Pongworn S, Dal S, Min H (2020). Ameliorative effects of ark clams (Scapharca subcrenata and Tegillarca granosa) on endothelial dysfunction induced by a high-fat diet. Applied Biological Chemistry 63: 73.

Qiao D, Ke C, Hu B, Luo J, Ye H, Sun Y, Yan X, Zeng X (2009). Antioxidant activities of polysaccharides from Hyriopsis cumingii. Carbohydr Polym 78: 199-204. DOI 10.1016/j. carbpol.2009.03.018.

Rosmorduc O, Wendum D, Corpechot C, Galy B, Sebbagh N et al. (1999). Hepatocellular hypoxia-induced vascular endothelial growth factor expression andangiogenesis in experimental biliary cirrhosis. American Journal of Pathology 155: 1065-1073.

Saad EA, EL-Demerdash RS, Abd EI-Fattah EM (2019). Mesenchymal stem cells are more effective than captopril in reverting cisplatin-induced nephropathy. Biocell 43: 73-79.

Safdari F, Rabbani M, Sharifabad AH (2017). Effect of acute and long term potassium bromide administration on spatial working memory in rat. Research in Pharmaceutical Sciences 12: 154-159.

Sai K, Hayashi M, Takagi A, Hasegawa R, Sofuni T, Kurokawa Y (1992). Effects of antioxidants on induction of micronuclei in rat peripheral blood reticulocytes by potassium bromate. Mutation Research 269: 113-118.

Shibuya M (2001). Structure and function of VEGF/VEGF-receptor system involved in angiogenesis. Cell Structure and Function 26: 25-35.

Silverstein DC, Hopper K (2009). Small Animal Critical Care Medicine. 1st Edition. Elsevier, Canada.

Singh P, Sankhla V (2010). In situ protective effect of curcumin on cadmium chloride induced genotoxicity in bone marrow chromosomes of Swiss albino mice. Journal of Cell and Molecular Biology 8: 57-64.

Smith WL, DeWitt DL, Garavito RM (2000). Cyclooxygenases: Structural, cellular, and molecular biology. Annual Review of Biochemistry 69: 145-182.

Solang M, Adriani M (2021). Anadara granosa substitution in feed to improve the zinc, protein of the feed, serum albumen, and body weight of malnourished rats. Food Research 5: 132-139. 
Speit G, Haupter S, Schutz P, Kreis P (1999). Comparative evaluation of the genotoxic properties of potassium bromate and potassium superoxide in V79 Chinese hamster cells. Mutation Research 439: 213-221.

Starek A, Starek-Świechowicz B (2016). Toxicological properties of potassium bromate. Journal of Pharma Reports 1: 1-9.

Tahir M, Rehman MU, Lateef A, Rehan Khan, Abdul Quaiyoom Khan et al. (2013). Diosmin protects against ethanol-induced hepatic injury via alleviation of inflammation and regulation of TNF- $\alpha$ and NF- $\mathrm{KB}$ activation. Alcohol 47: 131-139.

Tjio J, Whang J (1962). Chromosome preparatons of bone marrow cells without prior in vitro culture or in vivo colchicine administration. Stain Technology 37: 17-20.

Tomina D, Roman A, Condor D, Dinu C, Petruțiu SA (2007). Experimental rat model-Is it still used?-Review article. Human and Veterinary Medicine 9: 130-135.

Torimura T, Ueno T, Kin M, Ogata R, Sata M, Tanlkawa K (1999). VEGF participates in neovascularization and sinusoidal capillarization in HCC. Cells Hepatic Sinusoid 7: 300-301.

Umemura T, Sai K, Takagi A, Hasegawa R, Kurokawa Y (1995). A possible role for oxidative stress in potassium bromate (KBrO3) carcinogenesis. Carcinogenesis 16: 593-597.

Wahba HMA, Ibrahim TAA (2013). Protective effect of flaxseed oil and vitamin $\mathrm{E}$ on potassium bromate-induced oxidative stress in male rat. International Journal of Current Microbiology and Applied Sciences 2: 299-309.

Wang B, Li L, Chi CF, Ma JH, Luo HY, Xu YF (2013). Purification and characterisation of a novel antioxidant peptide derived from blue mussel (Mytilus edulis) protein hydrolysate. Food Chemistry 138: 1713-1719.

Wang L (2013). Tegillarca granosa extract haishengsu (HSS) suppresses expression of mdr1, BCR/ABL and sorcin in drug-resistant K562/ADM tumors in mice. Advances in Medical Sciences 58: 112-117.
Waterston RH, Lindblad-Toh K, Birney E, Rogers J, Abril JF, Agarwal $P$ (2002). Initial sequencing and comparative analysis of the mouse genome. Nature 420: 520-562.

Wójcik M, Ramadori P, Blaschke M, Sultan S, Khan S et al. (2012). Immunodetection of cyclooxygenase-2 (COX-2) is restricted to tissue macrophages in normal rat liver and to recruited mononuclear phagocytes in liver injury and cholangiocarcinoma. Histochemistry and Cell Biology 137: 217-233.

Xue H, Yan T, Jun L, Zhi S, Chun B, Shou G (2018). Tegillarca gransoa extract haishengsu inhibits tumor activity via a mitochondrial-mediated apoptotic pathway. Journal of Molecular Medicine Reports 17: 6828-6834.

Yancopoulos GD, Davis S, Gale NW, Rudge JS, Wiegand SJ, Holash J (2000). Vascular-specific growth factors and blood vessel formation. Nature 407: 242-248.

Yang L, Inokuchi S, Roh YS, Song J, Loomba R, Park EJ, Seki E (2013). Transforming growth factor- $\beta$ signaling in hepatocytes promotes hepatic fibrosis and carcinogenesis in mice with hepatocyte-specific deletion of TAK1. Gastroenterology 144: 1042-1054.

Yang XR, Qiu YT, Zhao YQ, Chi CF, Wang B (2019). Purification and characterization of antioxidant peptides derived from protein hydrolysate of the marine bivalve mollusk Tergillarca granosa. Marine Drugs 17: 251.

Yao X, Xu K (2003). Compiled: The Basic and Clinical of Liver Fibrosis. Shanghai: Shanghai Science and Technology Education Press.

Yu J, Hui AY, Chu ES, Cheng AS, Go MY et al. (2007). Expression of a cyclooxygenase-2 transgene in murine liver causes hepatitis. Gut 56: 991-999.

Zhang Y, Jiang L, Jiang L, Geng C, Li L, Shao J, Zhong L (2011). Possible involvement of oxidative stress in potassium bromate-induced genotoxicity in human HepG2 cells. Chemico-Biological Interactions 189: 186. 